\title{
Pollen Morphology and Ultrastructure
}

Polarity and Shape -38

Apertures -42

Pollen Wall - 45

Harmomegathy: The Harmomegathic Effect - 57

Size -57

Heterostyly and Pollen Dimorphism - 60

Aberrant Pollen Grains - 60

References -63 
The study of pollen should encompass all structural and ornamental aspects of the grain. Pollen morphology is studied using LM and SEM and is important to visualize the general features of a pollen grain, including, e.g., symmetry, shape, size, aperture number and location, as well as ornamentation. TEM investigations are used to highlight the stratification and the uniqueness of pollen wall layers as well as cytoplasmic features. The following sections explain the most important structural and sculptural pollen features a palynologist should observe.

\section{Polarity and Shape}

M ature pollen is shed in dispersal units. When the post-meiotic products become separated the dispersal unit is a single pollen grain, a monad. Post-meiotic products also become partly separated or remain permanently united, resulting in dyads (a rare combination), tetrads or polyads. Pollinaria are dispersal units of two pollinia including a sterile, interconnecting appendage (see "Glossary of Palynological Terms").

Pollen shape and aperture location relate directly to pollen polarity. The polarity is determined by the spatial orientation of the microspore in the meiotic tetrad and can be examined in the tetrad stage (Fig. 1). The polar axis of each microspore/ pollen runs from the proximal pole, orientated towards the tetrad center, to the distal pole of the microspore/pollen (Fig. 2). The equatorial plane is located at the microspore's center, perpendicular to the polar axis (Fig. 2). Therefore, the equatorial plane divides the microspore/pollen into a proximal and a distal half, comparable to the northern and southern hemisphere of our planet Earth.

The polarity gives rise to the polar and to the equatorial view. In dicots there is usually one polar

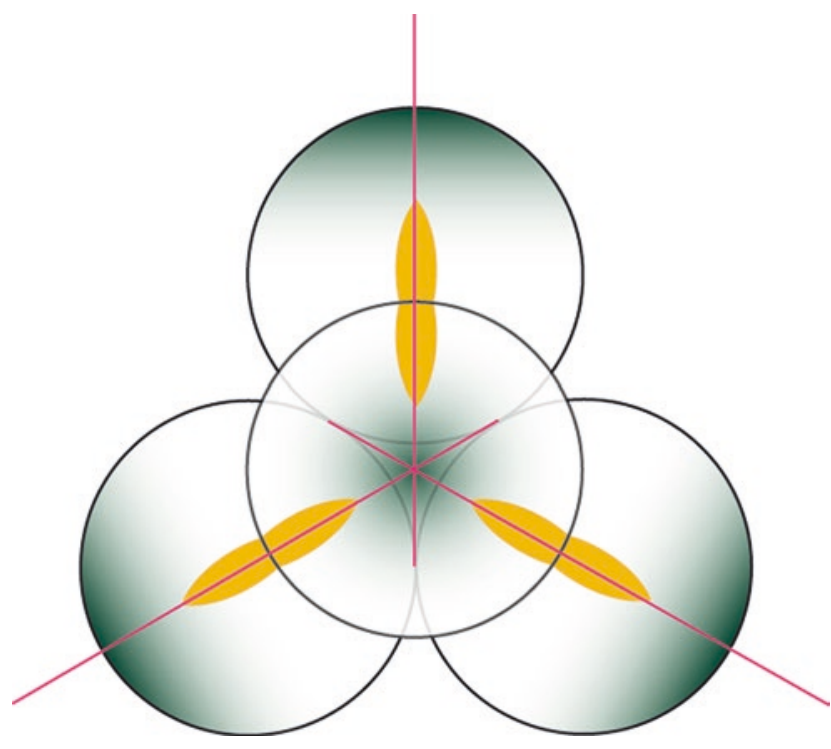

Fig. 1 Tetrad stage. Orientation of microspores/pollen in the tetrad; distal poles shaded green
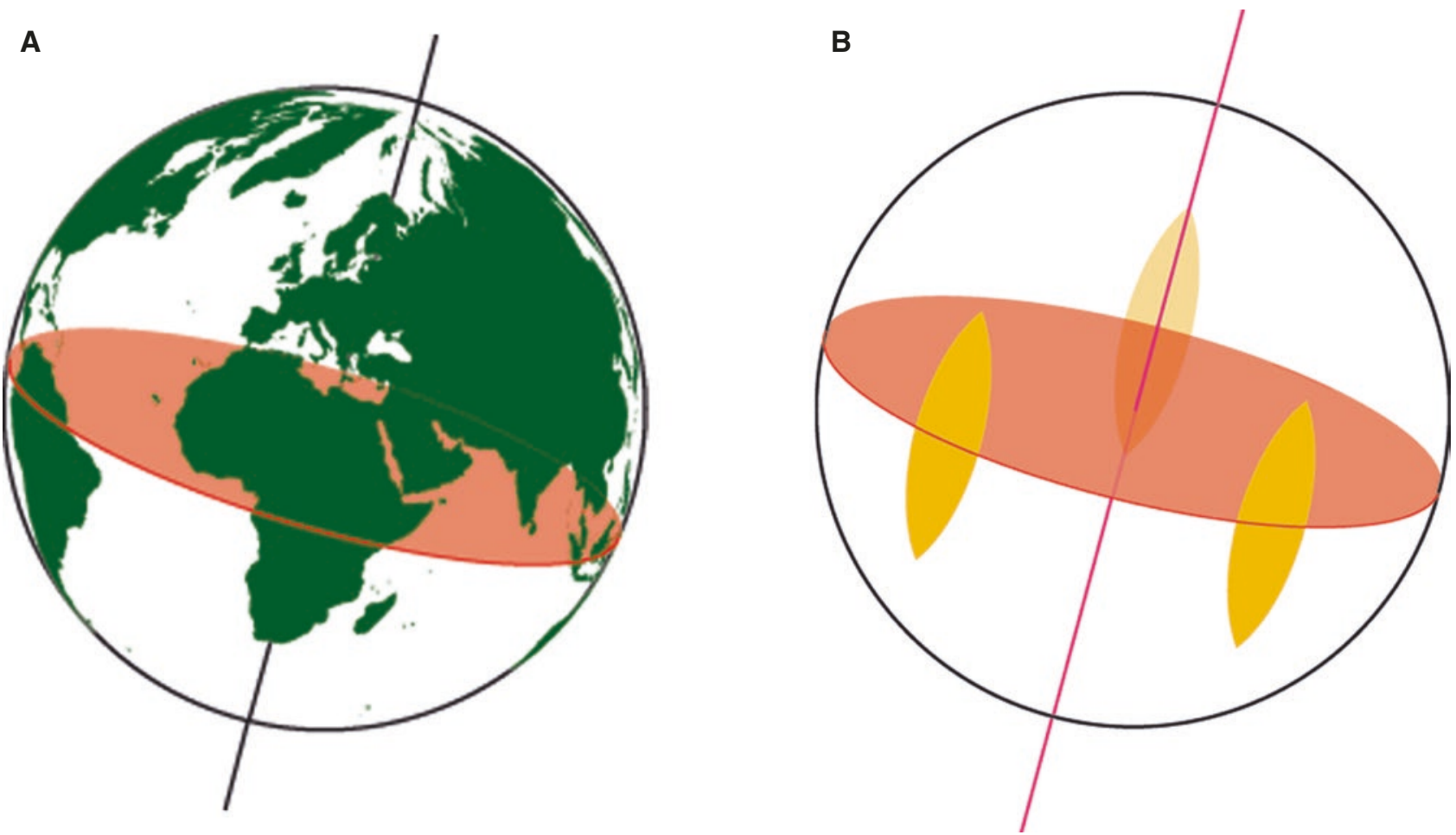

Fig. 2 Polar axis and equatorial plane. A-B. Polar axis and equatorial plane 
A

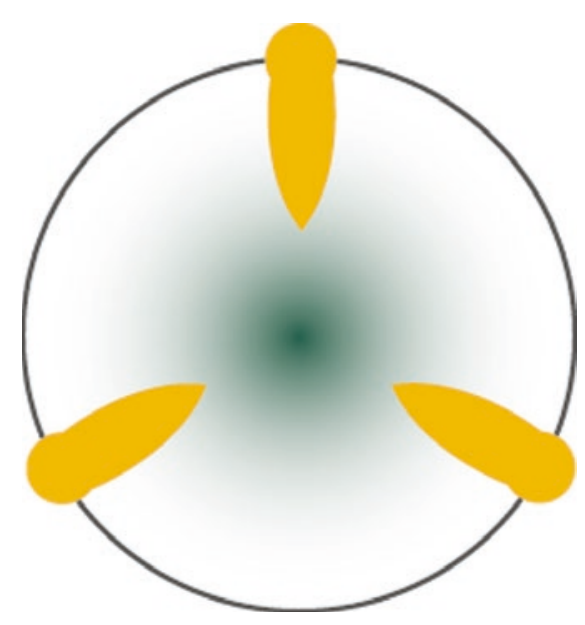

C

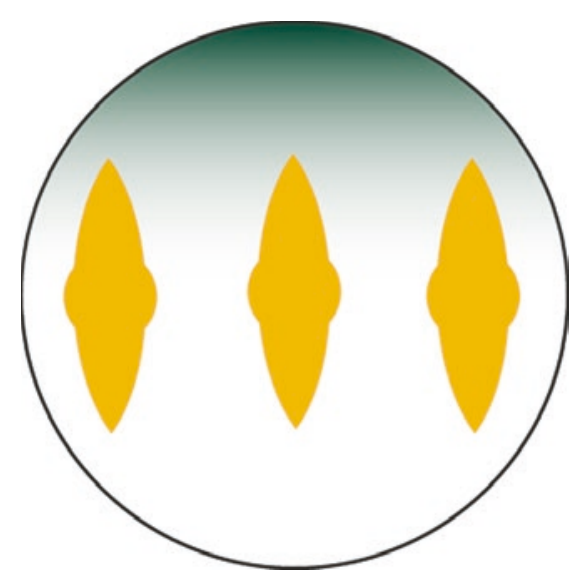

B

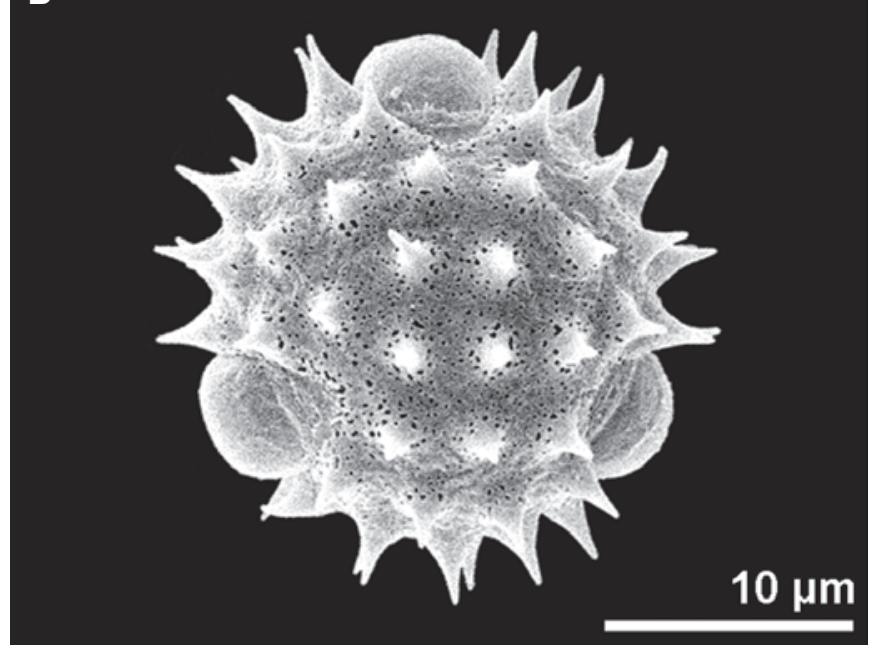

D

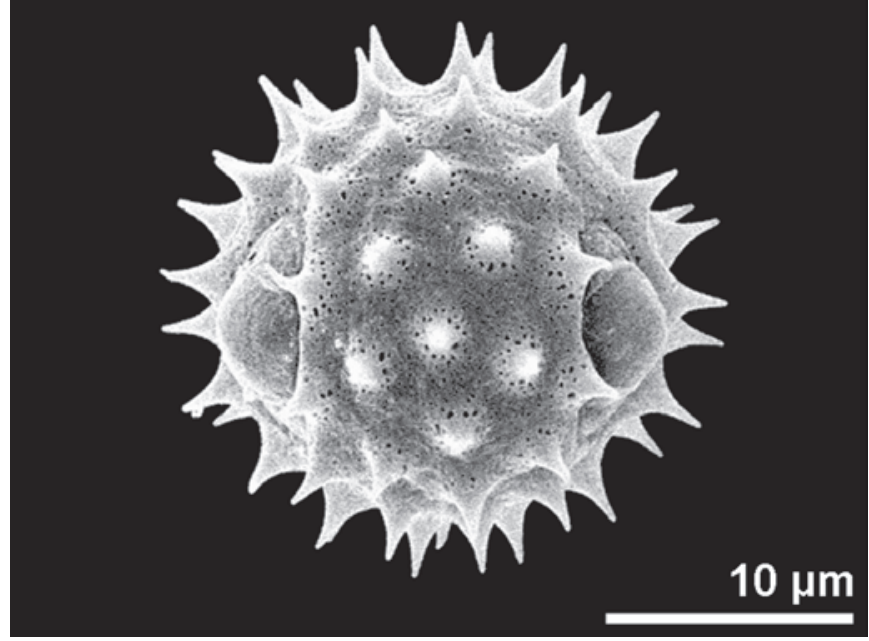

Fig. 3 Polarity of pollen in dicots. A-B. Bellis perennis, Asteraceae, polar view. C-D. Bellis perennis, Asteraceae, equatorial view

and one equatorial view (Fig. 3). In monocots, due to the mostly distal position of apertures, there are four views: distal polar, proximal polar, and two different equatorial views (Fig. 4).

Isopolar pollen has identical proximal and distal poles, thus the equatorial plane is a symmetry plane. In heteropolar pollen the proximal and distal halves differ (Fig. 5).

The various arrangements of the four microspores within tetrads depend on the simultaneous or successive type of cytokinesis and on the type of intersporal wall formation. The spatial arrangement of microspores after simultaneous cytokinesis is a tetrahedral (or rarely decussate) tetrad (Fig. 6A). This tetrad types may have systematic relevance, e.g., all species within the genus Rhododendron are characterized by tetrahedral tetrads. The spatial arrangement of microspores after successive cyto- kinesis leads to different morphological tetrad types, which can be differentiated into planar (tetragonal, linear, T-shaped) and/or non-planar (decussate or tetrahedral) tetrads (Fig. 6B). These morphotypes have no systematic relevance, as tetrads may vary within a genus/species, e.g., in Typha tetrads may be tetragonal, T-shaped and/or linear (Furness and Rudall 2001; Copenhaver 2005; see also "lllustrated Pollen Terms").

P/E ratio (Fig. 7) refers to the length of the polar axis $(P)$ between the two poles compared to the equatorial diameter (E). In isodiametric pollen the polar axis is \pm equal to the equatorial diameter. In prolate pollen the polar axis is longer than the equatorial diameter. In oblate pollen the polar axis is shorter than the equatorial diameter. Pollen shape refers to the 3-dimensional form of a pollen grain in relation to the $\mathrm{P} / \mathrm{E}$ ratio. A pollen grain can, for 
A

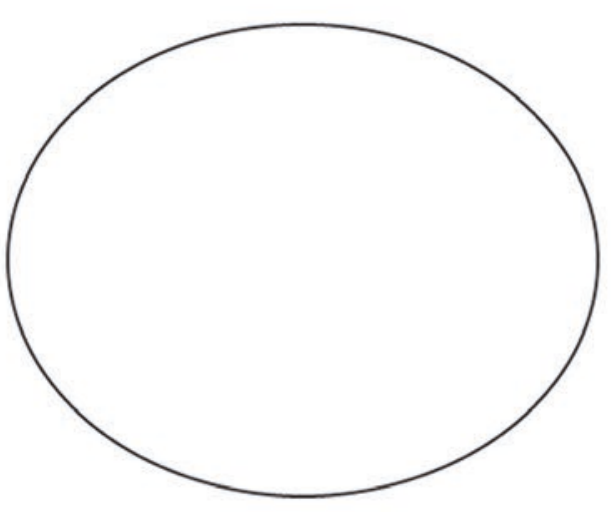

C

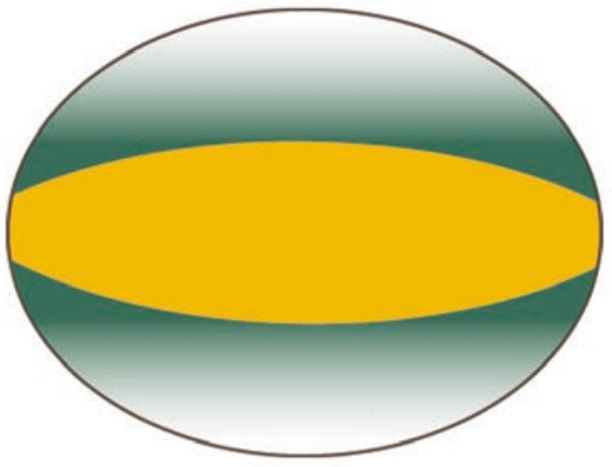

E

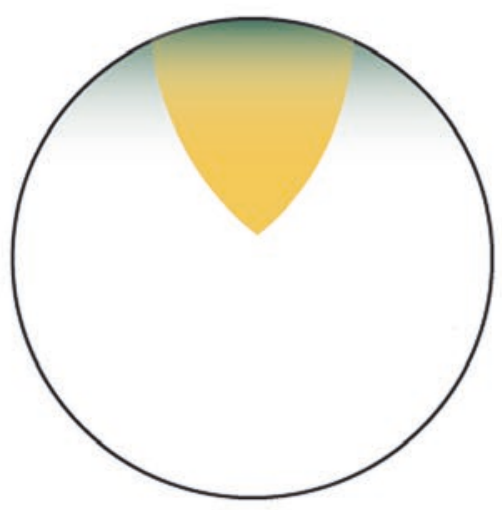

G

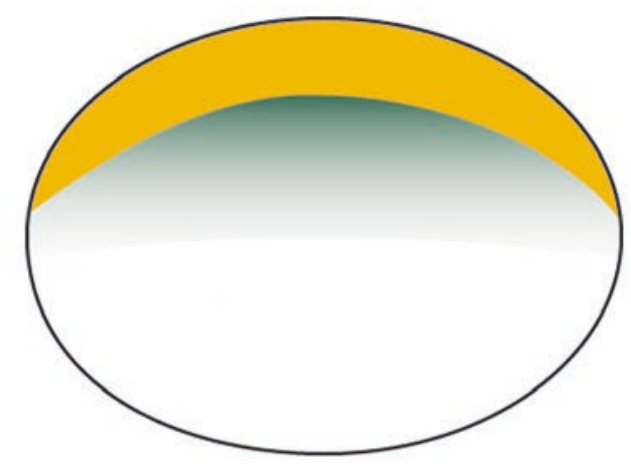

B

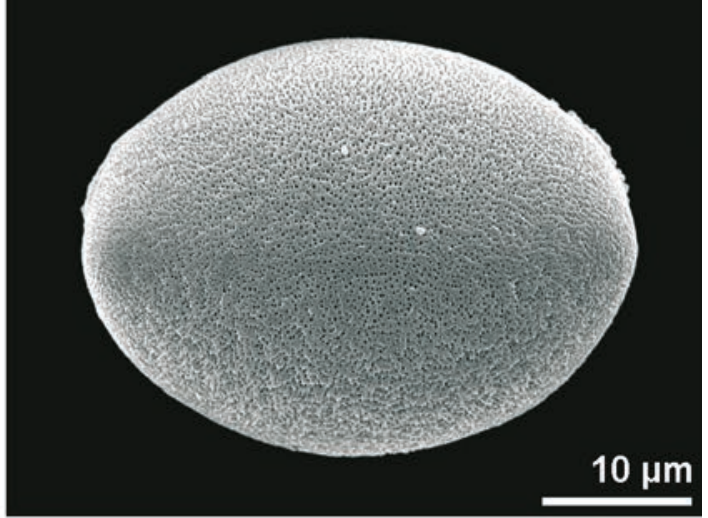

D

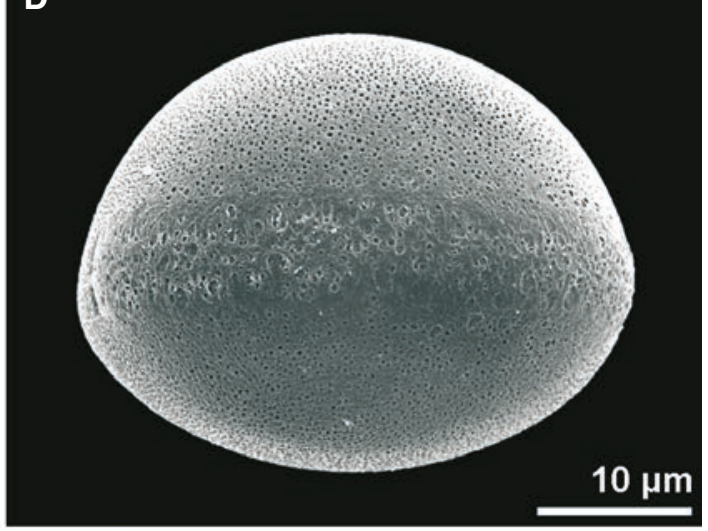

$\mathbf{F}$

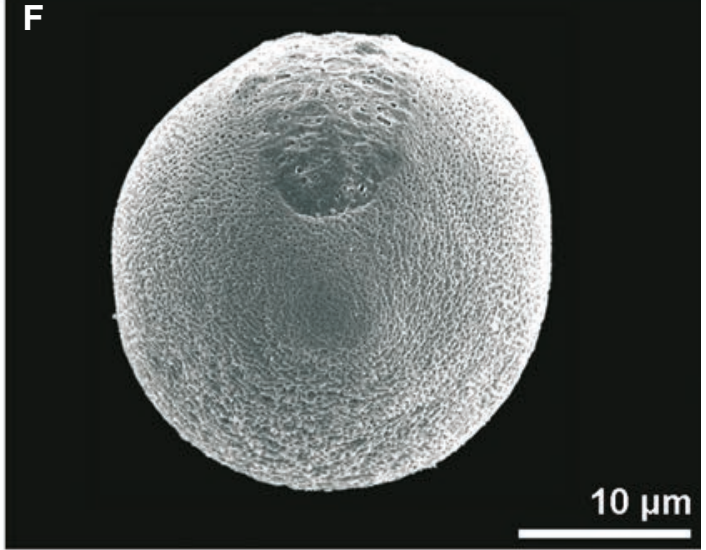

H

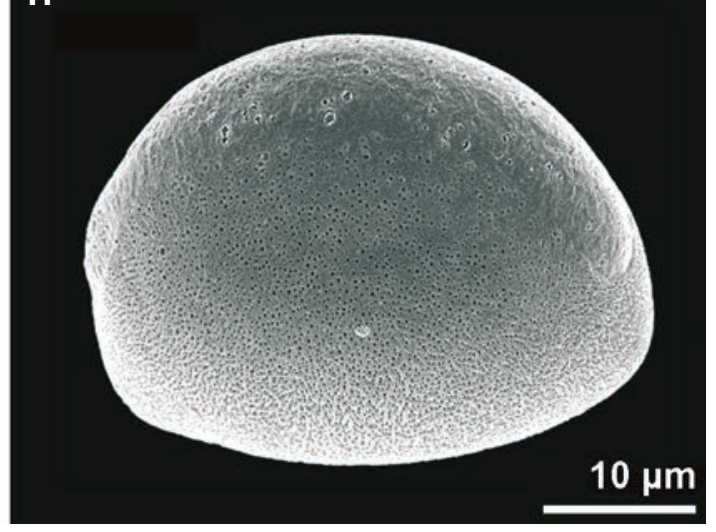

Fig. 4 Polarity of pollen in monocots (Allium paradoxum, Alliaceae). A-B. Proximal polar view. C-D. Distal polar view. E-F. Equatorial view (short axis). G-H. Equatorial view (long axis)

40 | GENERAL CHAPTERS 
A

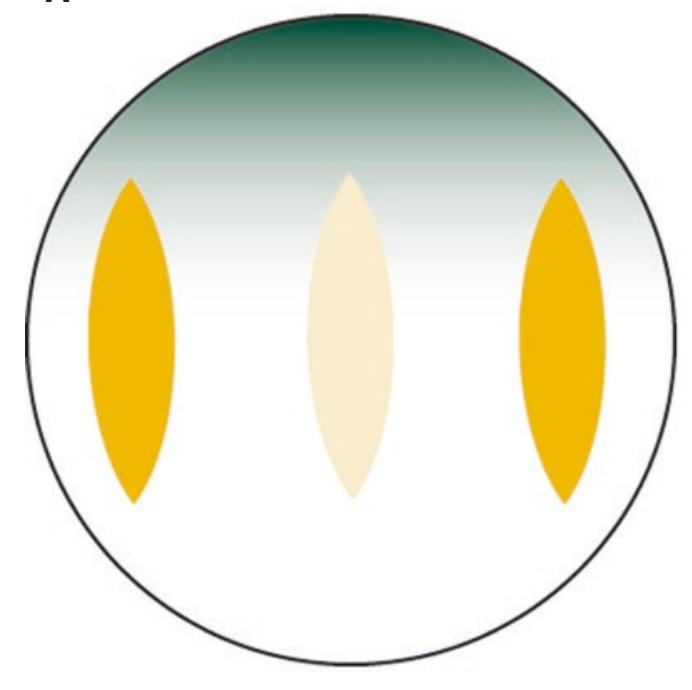

\section{B}

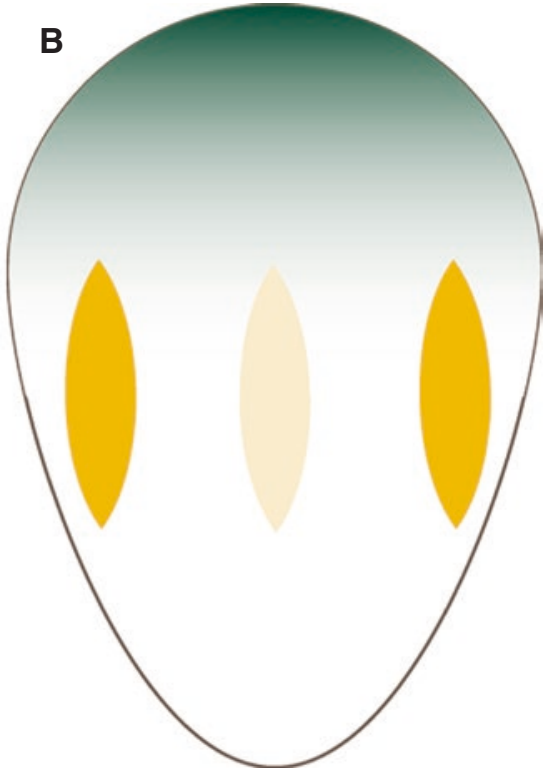

Fig. 5 Pollen symmetry. A. Isopolar pollen. B. Heteropolar pollen

A

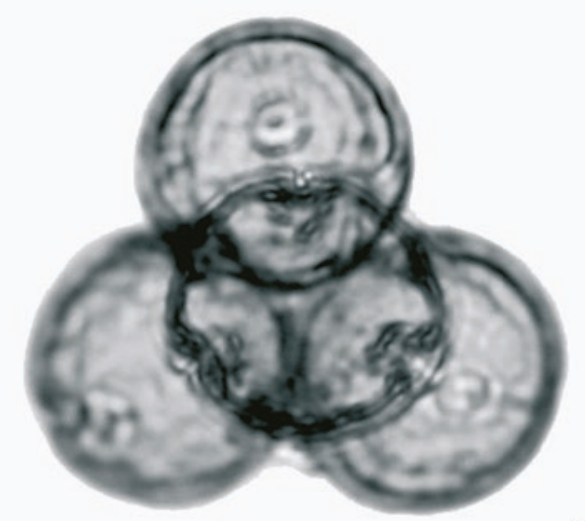

B

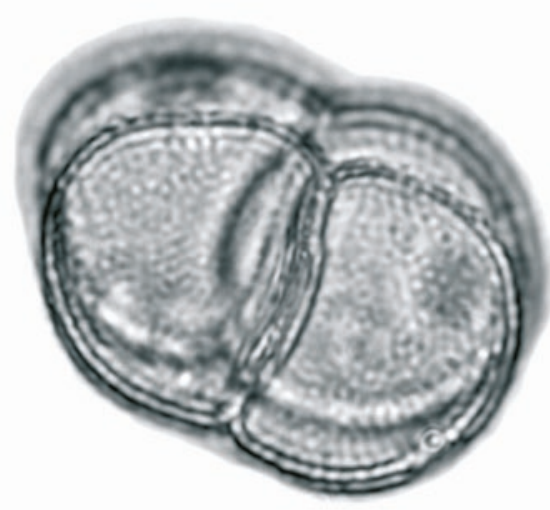

$10 \mu \mathrm{m}$

Fig. 6 Pollen arrangements in tetrads. A. Tetrahedral tetrad, Fagus sp., Fagaceae, fossil, Quaternary, Austria; apical view. B. Planar tetrad, Typha latifolia, Typhaceae, fossil, Quaternary, Austria
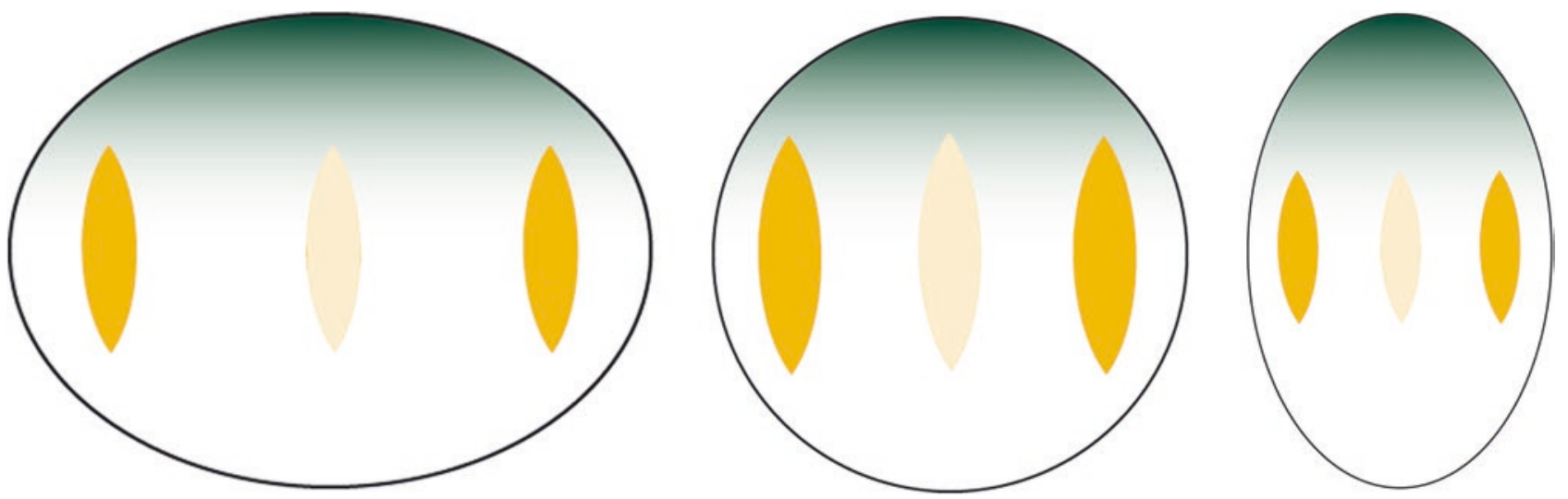

Fig. 7 P/E ratio of pollen. Schematic drawings of oblate (left), isodiametric (middle), and prolate (right) pollen 
A

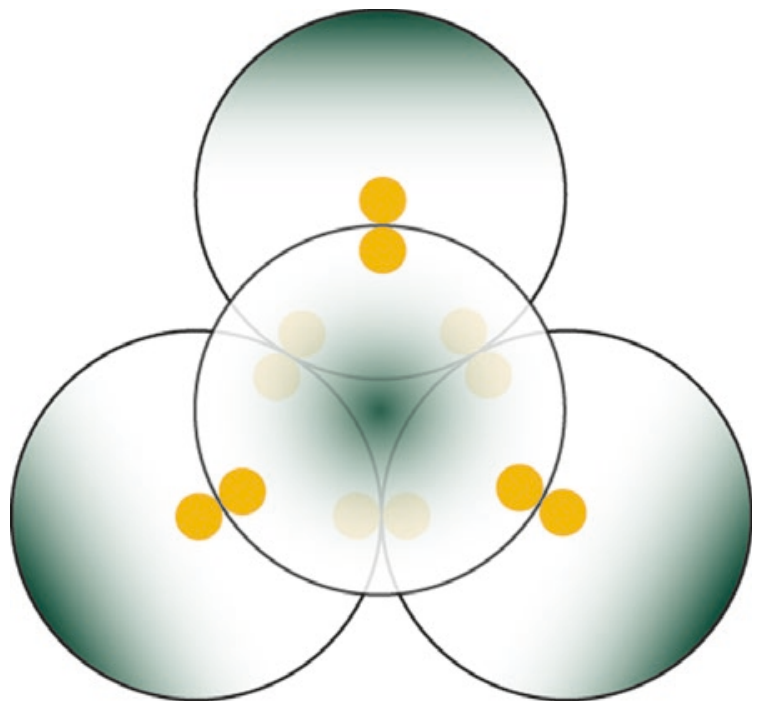

B

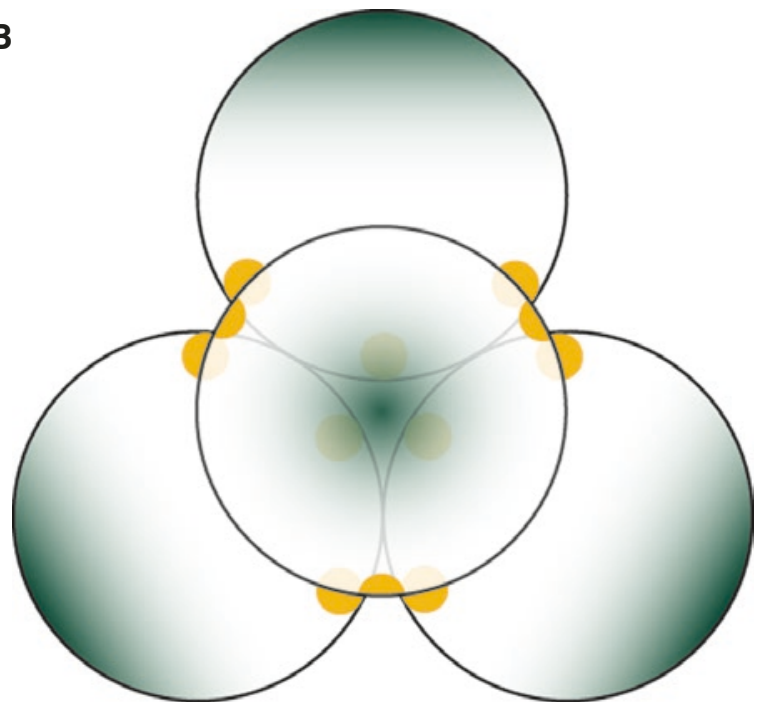

Fig. 8 Aperture arrangement. A. Fischer's law, apertures in pairs. B. Garside's law, apertures in a group of three

example, be spheroid-, cup-, boat-, cube-, tetrahedral-, triangular dipyramid-, hexafoil dipyramid-, triangular prism-, pentagonal prism-, or hexagonal prism shaped (see "lllustrated Pollen Terms").

In pollen grains with three apertures, two types of aperture arrangement occur after simultaneous cytokinesis (Fig. 8). Fischer's law refers to the most frequent arrangement where a pair of apertures occurs at six points in a tetrad (e.g., Ericaceae, permanent tetrads). Garside's law refers to the unusual arrangement of apertures where a group of three apertures occur at four points in the tetrad (probably restricted to Proteaceae, no permanent tetrads; Blackmore and Barnes 1995) (Fig. 8).

\section{Apertures}

A $\mathrm{n}$ aperture is a region of the pollen wall that differs significantly from its surroundings in morphology and/or anatomy. The aperture is presumed to function as the site of germination and to play a role in harmomegathy. Pollen grains lacking apertures are called inaperturate (Furness 2007). The aperture definition fits both angiosperm and gymnosperm pollen, but in gymnosperms the type of aperture (e.g., leptoma; germination area) usually differs from that in angiosperms.

The polarity of the pollen grain determines the aperture terminology. A circular aperture is termed a porus if situated equatorially or globally; if situated distally, it is called an ulcus. An elongated aperture is termed a colpus if situated equatorially or globally; if situated distally, it is termed a sulcus. A combination of porus and colpus is termed a colporus; colpori are situated equatorially or globally.
In heteroaperturate pollen two different types of apertures (single and/or combined) are present in a combination of colpi with colpori or pori. A circular or elliptic aperture with indistinct margins is termed a poroid. Additional rare combinations of ekto- and endoapertures, mostly observed in LM, include pororate and colporoidate (Fig. 9). Pollen grains that have compound apertures composed of circular ektopori and endopori are termed pororate. Compound apertures composed of a colpus (ektoaperture) with an indistinct endoaperture are termed colporoidate. When the colpus has a clear bulge in the equatorial region of a pollen grain it is termed geniculum (Fig. 9D).

The number of equatorial apertures (pori, colpi, colpori) is indicated by the prefixes di-, tri-, tetra-, penta- or hexa-. Writing numbers instead of prefixes is in common use, e.g., 4-porate or tetraporate, 6-colpate or hexacolpate. In this book we prefer the use of prefixes. For pollen grains with more than three apertures, positioned at the equator, the term stephanoaperturate (stephanoporate, stephanocolpate, stephanocolporate) is used together with the aperture number (e.g., stephano(4)porate or 4-porate, stephanoporate). Pollen grains with globally distributed apertures are termed pantoaperturate.

Apertures are normally covered by an exinous layer, the aperture membrane. The aperture membrane can be ornamented, e.g., covered with various exine elements, or it is psilate (smooth). The aperture can also be covered by an operculum, a distinctly delimited exine structure, covering the aperture like a lid (Halbritter and Hesse 1995; Furness and Rudall 2003).

Number, type, and position of apertures are genetically determined and usually the same within 
A

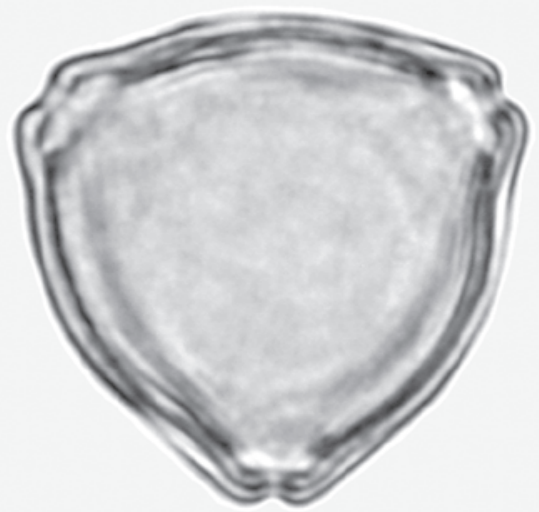

$10 \mu \mathrm{m}$

C

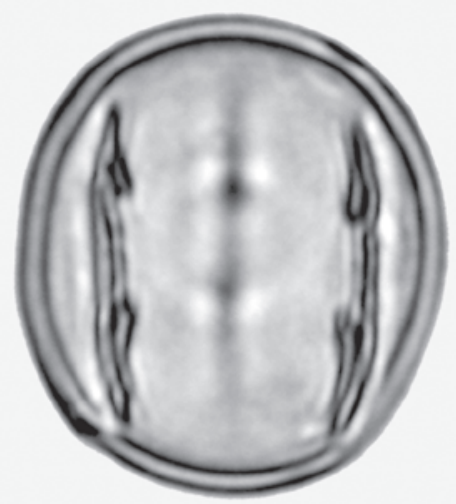

B

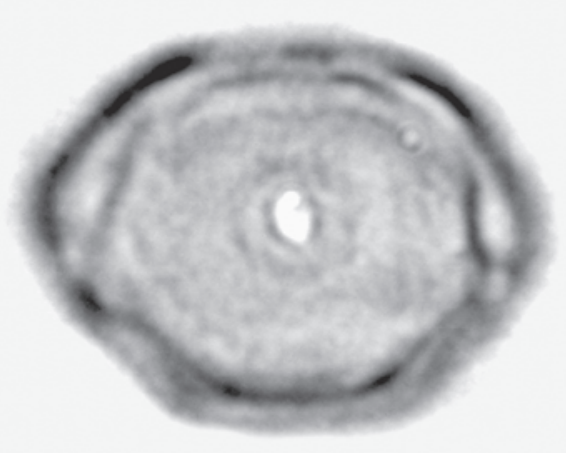

$10 \mu \mathrm{m}$

D
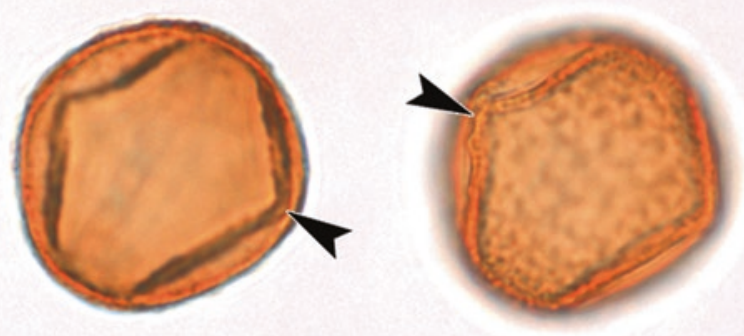

$10 \mu \mathrm{m}$

Fig. 9 Special aperture features observed in LM. A-B. Corylus sp., Betulaceae, fossil, Quaternary, Austria, pororate pollen in polar and equatorial view. C. Eucommia sp., Eucommiaceae, fossil, middle Miocene, Austria, colporoidate pollen in equatorial view. D. Quercus petrea, Fagaceae, pollen with geniculum (arrowhead), optical section (left) and upper focus (right)

a species, but may also vary (e.g., Alnus is usually 5-porate, but number of pori can vary from 3 to 6).

A pseudocolpus occurs in heteroaperturate pollen and is presumed to be non-functional. Pseudocolpi mostly alternate with colpori (e.g., in Boraginaceae, Lythraceae) or are flanking each colporus (in Acanthaceae). For examples, see "lllustrated Pollen Tems." Pseudocolpi are believed to play a role in harmomegathy, but their effect has been poorly studied.

Pre-(prae-)pollen (Fig. 10) is characterized by proximal and sometimes additional distal apertures, and by presumed proximal germination. Pre-pollen are microspores of certain extinct basal seed plants occurring from the Late Devonian until the Cretaceous. Proximal germination is typical for spores.

Spores germinate at the tetrad mark (Fig. 11), the so-called laesura (for an extensive overview, see

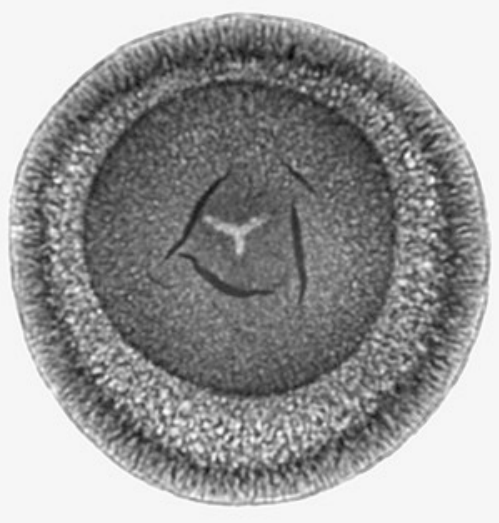

$10 \mu \mathrm{m}$

Fig. 10 Pre-pollen. Nuskoissporites sp., fossil, Permian, Austria, polar view 
Tryon and Lugardon 1991). The tetrad mark is situated at the proximale pole (proximal germination).

Proximal germination is a rare exception in seed plants (Fig. 12), e.g., Beschorneria yuccoides (Agavaceae) and Annona muricata (Annonaceae). In the two cases, this proximally situated aperture (germination area) is functionally replacing the dysfunctional sulcus (Hesse et al. 2009). In Beschorneria, pollen grains forming the tetrads are loosely interconnected and separate frequently. In this special case, the sulcus (distal) is not functional, whereas the proximal face, with a highly reduced exine, functions as germination site. In Annona, the microspores rotate within the tetrad during development and the original distally placed sulcus becomes proximally positioned (Tsou and Fu 2002).

A

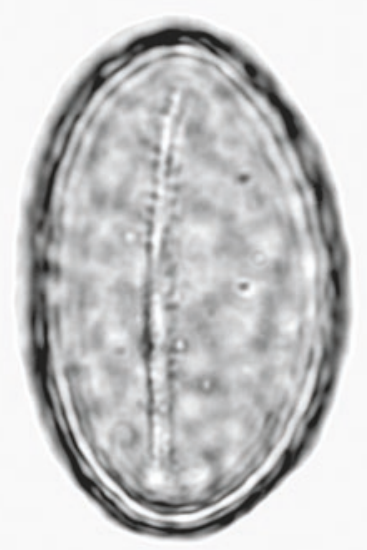

$10 \mu \mathrm{m}$

C

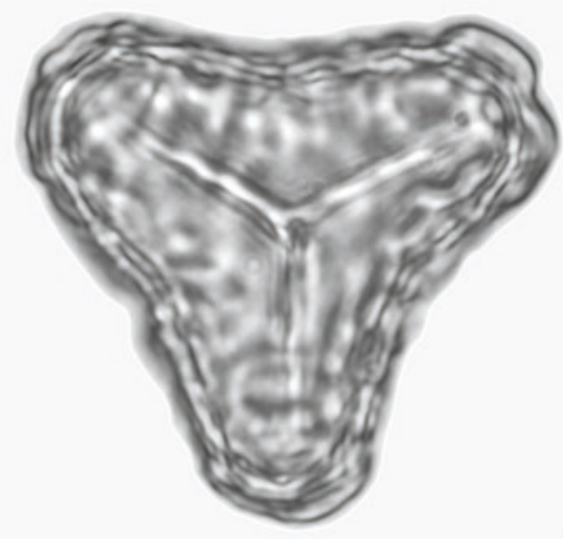

$10 \mu \mathrm{m}$
The aperture usually acts as the (exclusive) germination site. In inaperturate angiosperm pollen the pollen tube can protrude at any given site. In taxoid gymnosperm pollen the exine ruptures during hydration at a specialized region, the leptoma, and is subsequently shed (Fig. 13A-B). The protoplast (enclosed by the intine) is released and a pollen tube can be formed anywhere (resembling functionally an inaperturate pollen grain). Furthermore some angiosperm taxa shed the exine before pollen tube formation, e.g., in some Annonaceae, Araceae. Within the Araceae, a shed pollen wall has been observed in several taxa, e.g., Amorphophallus, Taccarum (Ulrich et al. 2017). The outer pollen wall (composed of polysaccharide) splits immediately in water and sheds soon afterwards. Subsequently, the naked protoplast is

B

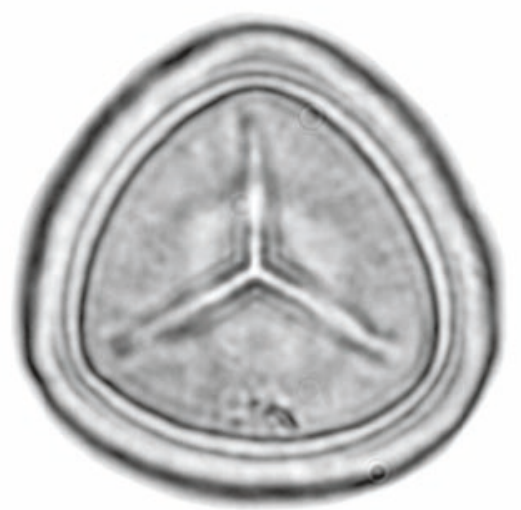

$10 \mu \mathrm{m}$

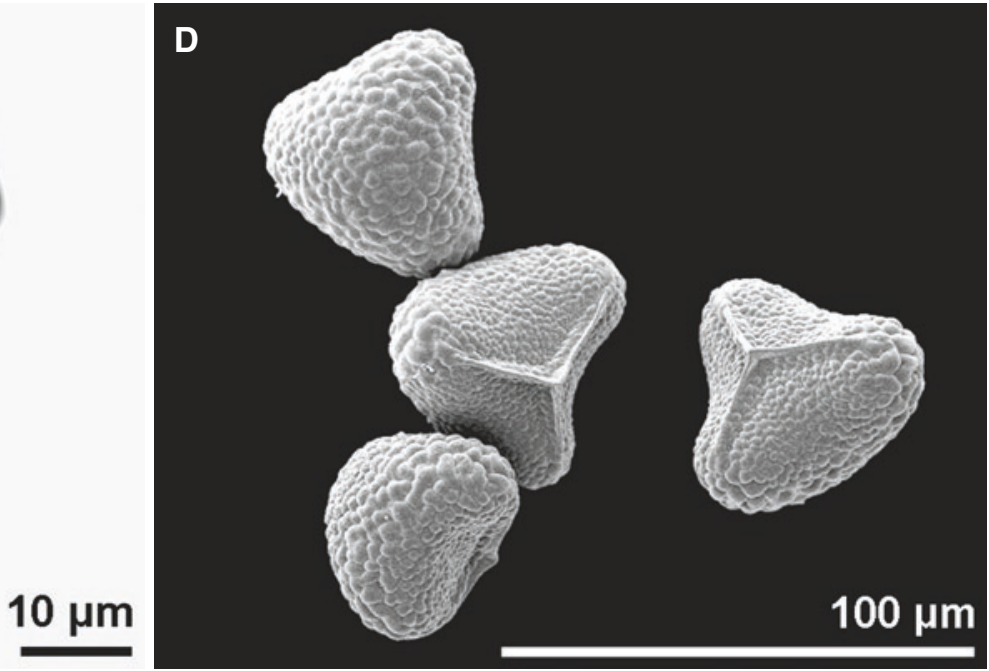

Fig. 11 Tetrad mark in spores. A. Polypodium sp., Polypodiaceae, fossil, monolete tetrad mark, middle Miocene, Austria, polar view. B. Sphagnum sp. Sphagnaceae, fossil, trilete tetrad mark, middle Miocene, Austria, polar view. C. Pteridaceae indet., fossil, middle Miocene, Austria, trilete tetrad mark, polar view. D. Cryptogamma crispa, Pteridaceae, trilete tetrad mark 

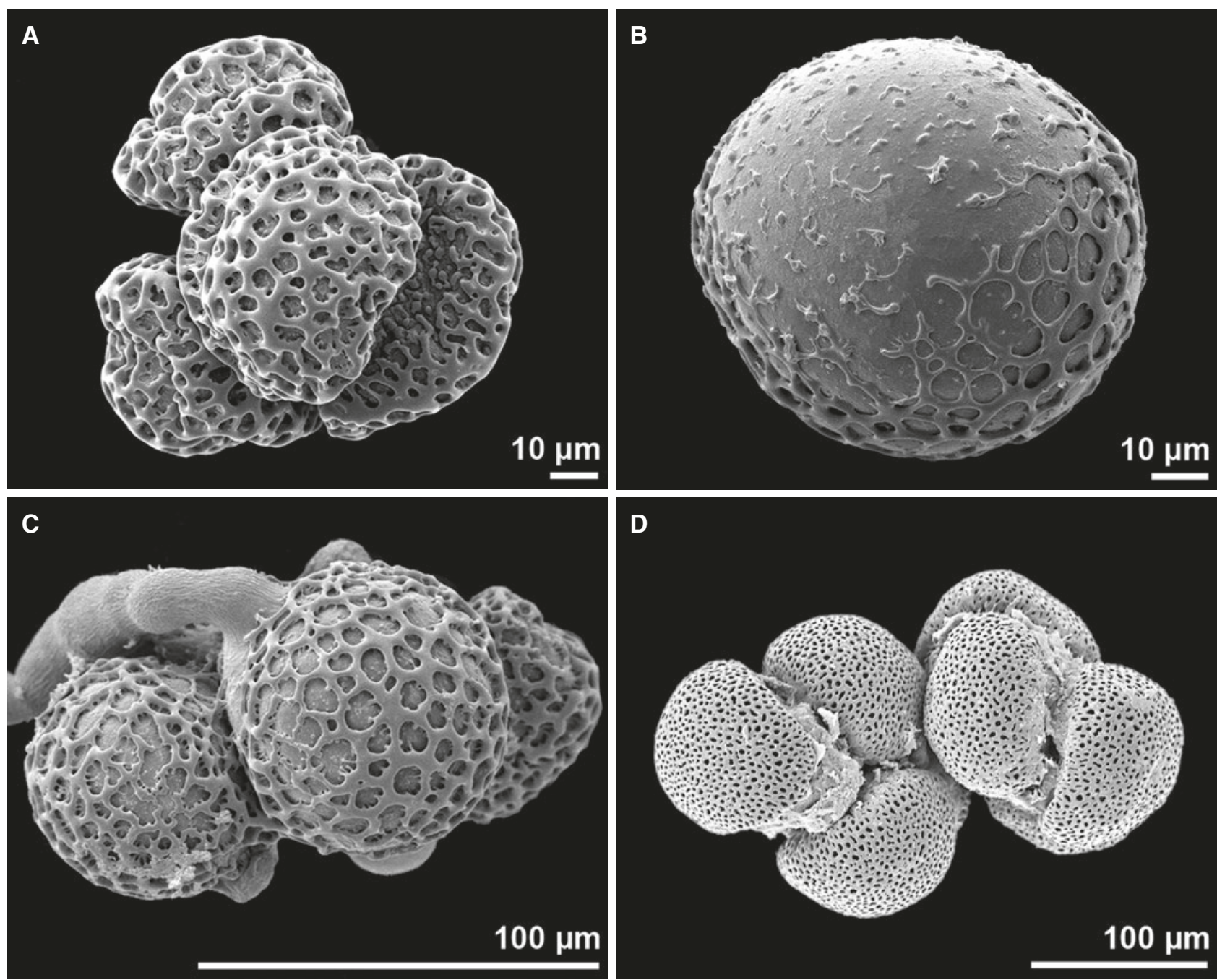

Fig. 12 Proximal germination. A. Beschorneria yuccoides (Agavaceae), dry tetrad. B. Beschorneria yuccoides (Agavaceae), monad, proximal polar view, proximal face functions as germination site. C. Beschorneria yuccoides (Agavaceae), germinated tetrad, note proximal germination. D. Annona muricata (Annonaceae), mature tetrads, sulcus hidden in proximal position

floating in water and germinates about 1 hour after shedding (Fig. 13C-D).

During germination, usually a single pollen tube is formed. In some cases, instant pollen tube-like structures are simultaneously developed at all apertures (Fig. 14). The formation of these pollen tubelike structures, in relation with moisture, is interpreted as a pre-germinative process that takes place during dehiscence (Blackmore and Cannon 1983).

\section{Pollen Wall}

T he internal construction of the pollen wall is termed structure. Ornamenting elements on the pollen surface (ornamentation) are summarized under the term sculpture or sculpturing. However, it is not always possible to distinguish between structure and sculpture (e.g., free-standing columellae).

\section{Structure}

In general, the pollen wall (sporoderm) of seed plants is formed by two main layers: the outer exine and the inner intine (Fig. 15). The exine consists mainly of sporopollenin, which is an acetolysis- and decay-resistant biopolymer. The intine is mainly composed of cellulose and pectin. Commonly, the pollen wall in aperture regions is characterized by the reduction of exine structures or by a deviant exine, and a thick, often bilayered intine.

Two layers within the exine are distinguished: an inner endexine and an outer ektexine. In tectate pollen the ektexine usually consists of a basal foot layer, an infratectum (e.g., columellae) and a tectum, the endexine is a mainly unstructured layer (Fig. 16A-C). There are many deviations from this principal construction: layers may be thickened, variably structured or lacking. When the pollen 


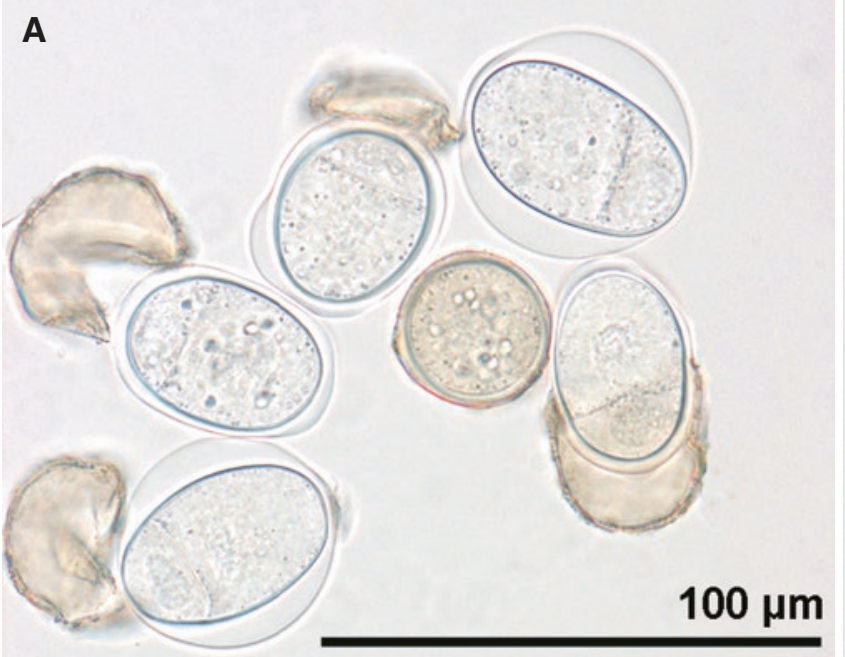

B
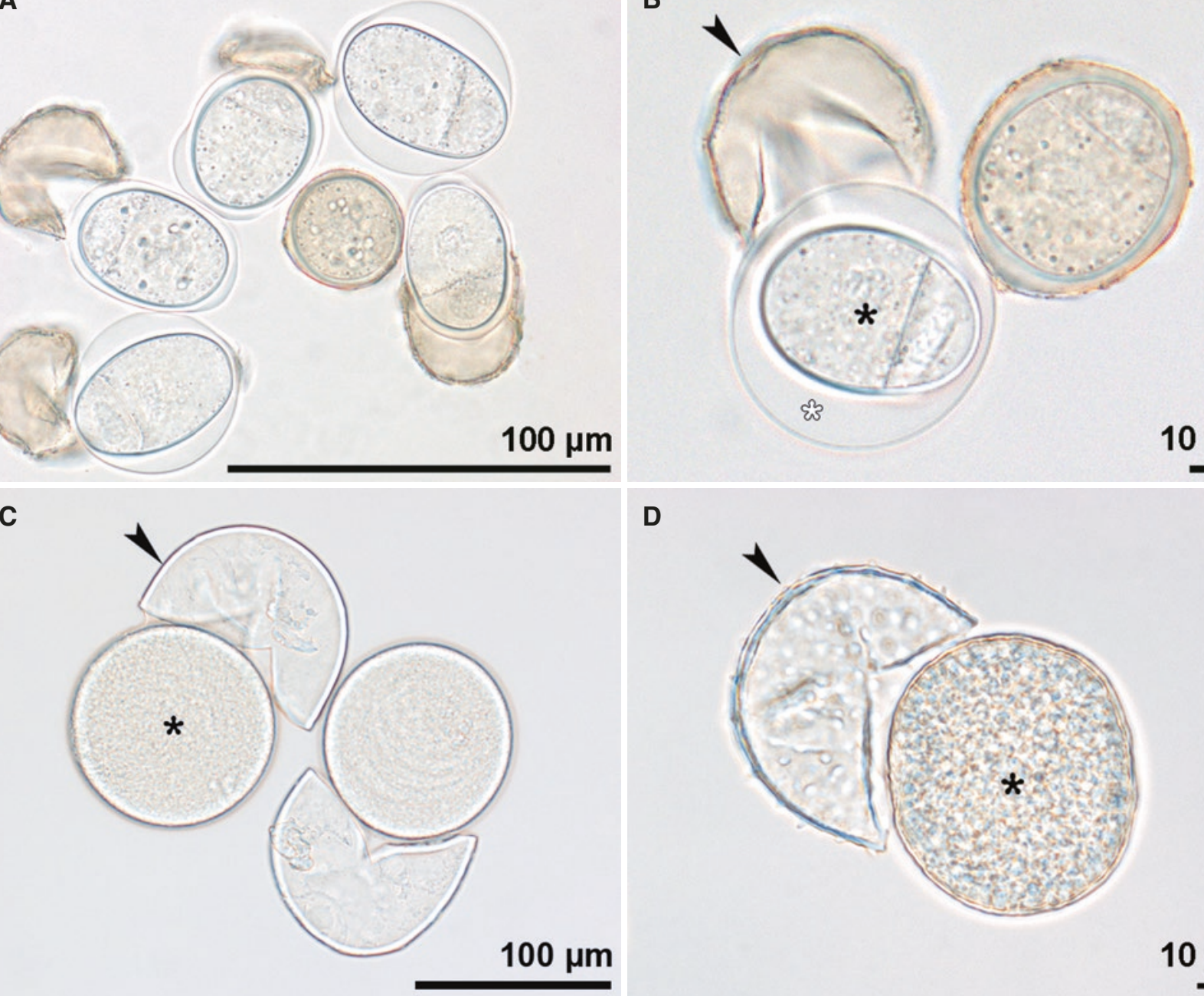

$10 \mu \mathrm{m}$

D

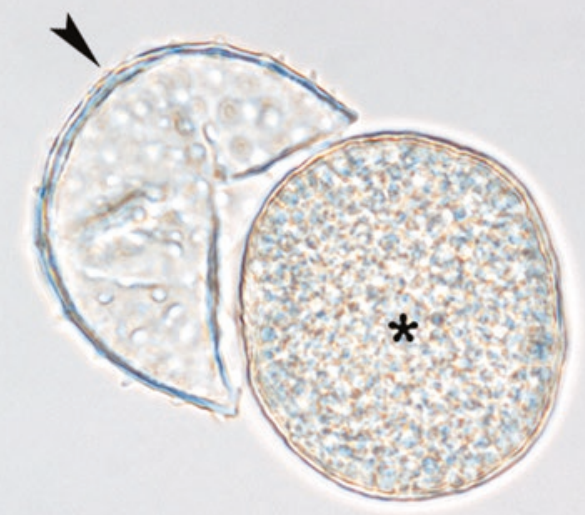

$10 \mu \mathrm{m}$

Fig. 13 Exine/pollen wall shedding. A. Cephalotaxus sp., Cephalotaxaceae, fresh pollen in water. B. exine (arrowhead) shedding prior to pollen tube formation, released protoplast (black asterisk) enclosed by a thick swelled intine (white asterisk). C. Taccarum weddellianum, Araceae, pollen wall shedding, released protoplast (black asterisk) and shed outer pollen wall (arrowhead). D. Amorphophallus mangelsdorffii, Araceae, pollen wall shedding, released protoplast (black asterisk) and shed outer pollen wall (arrowhead)
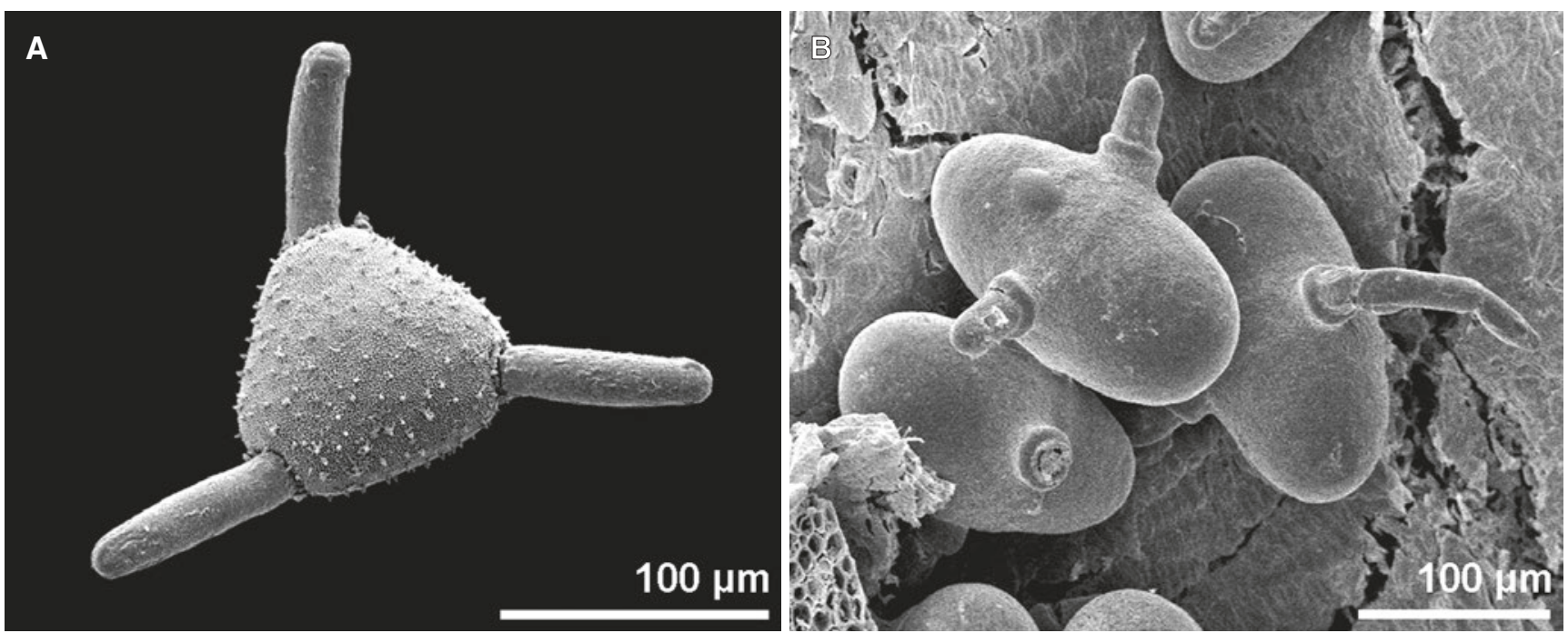

Fig. 14 Instant pollen tubes. A. Scabiosa caucasica, Dipsacaceae. B. Morina longifolia, Morinaceae 46 | GENERAL CHAPTERS 
grain is lacking a tectum it is termed atectate (Fig. 16D-F). In apertural regions the pollen wall is generally characterized by a different exine construction.

The terms sexine for the outer, structured, and nexine for the inner, unstructured exine layer are widely used in light microscopy, but do not fully correspond to ekt- and endexine, respectively. When a cavity between the sexine and nexine is present in the interapertural area, this is termed cavea (Fig. 17).

\section{Sporopollenin}

John (1814) and Braconnot (1829) introduced the terms "pollenin" and "sporonin" for the resistant exine material of pollen and spores. Zetzsche et al. (1931) then combined the terms into "sporopollenin," that is the major component of the exine found in most pollen and spores, except in filiform seagrass pollen (e.g., Dobritsa et al. 2009; Jardine et al. 2015). Sporopollenin is a complex biopolymer and extremely resistant to
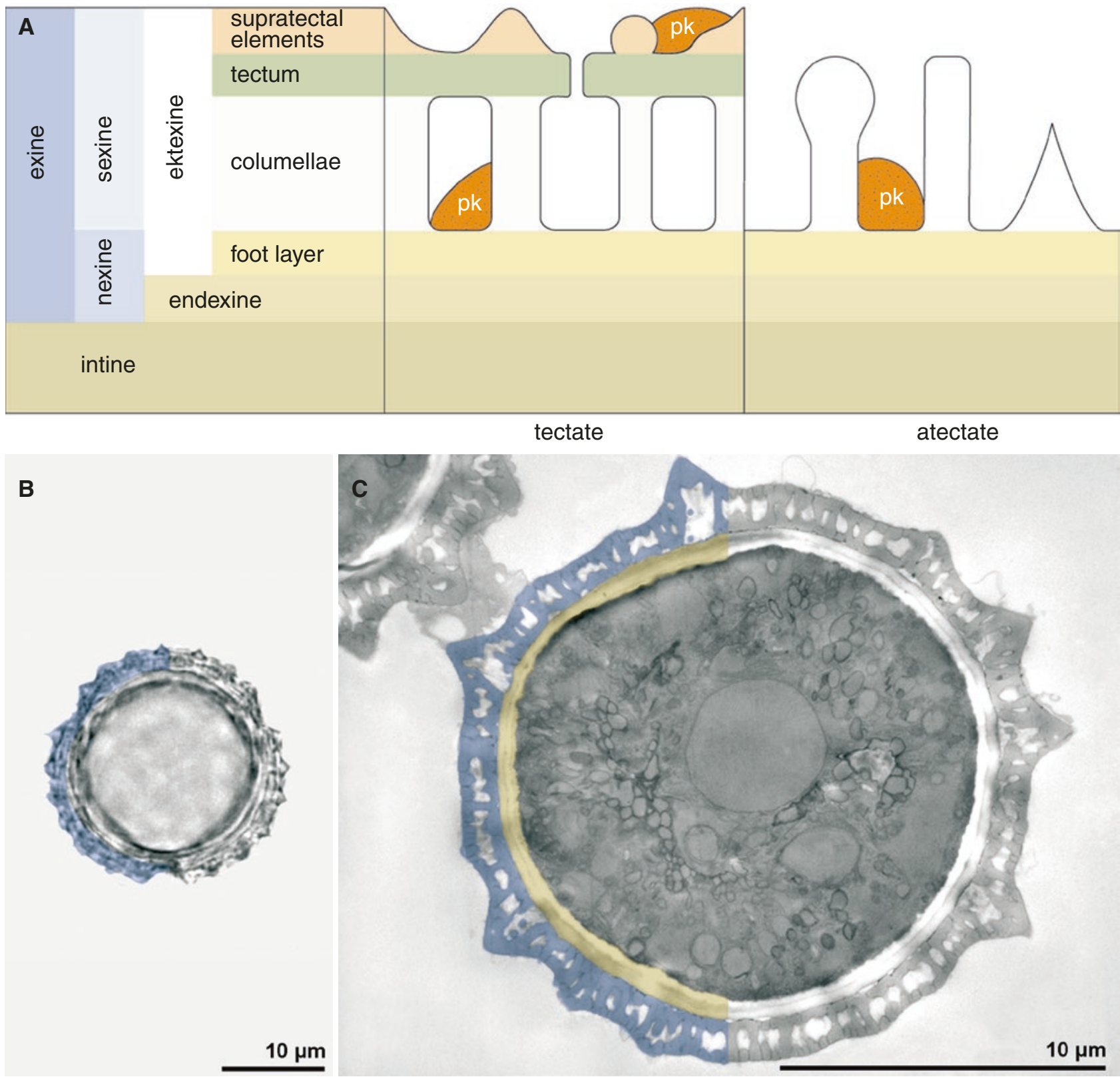

Fig. 15 Pollen wall stratification. A. Schematic cross section of pollen wall, pk: pollenkitt. B. Ambrosia artemisiifolia, Asteraceae, optical view showing both intine and exine; acetolyzed. C. Ambrosia artemisiifolia, Asteraceae, cross section showing both intine (yellow) and exine (blue); modified Thíery-test 
A D
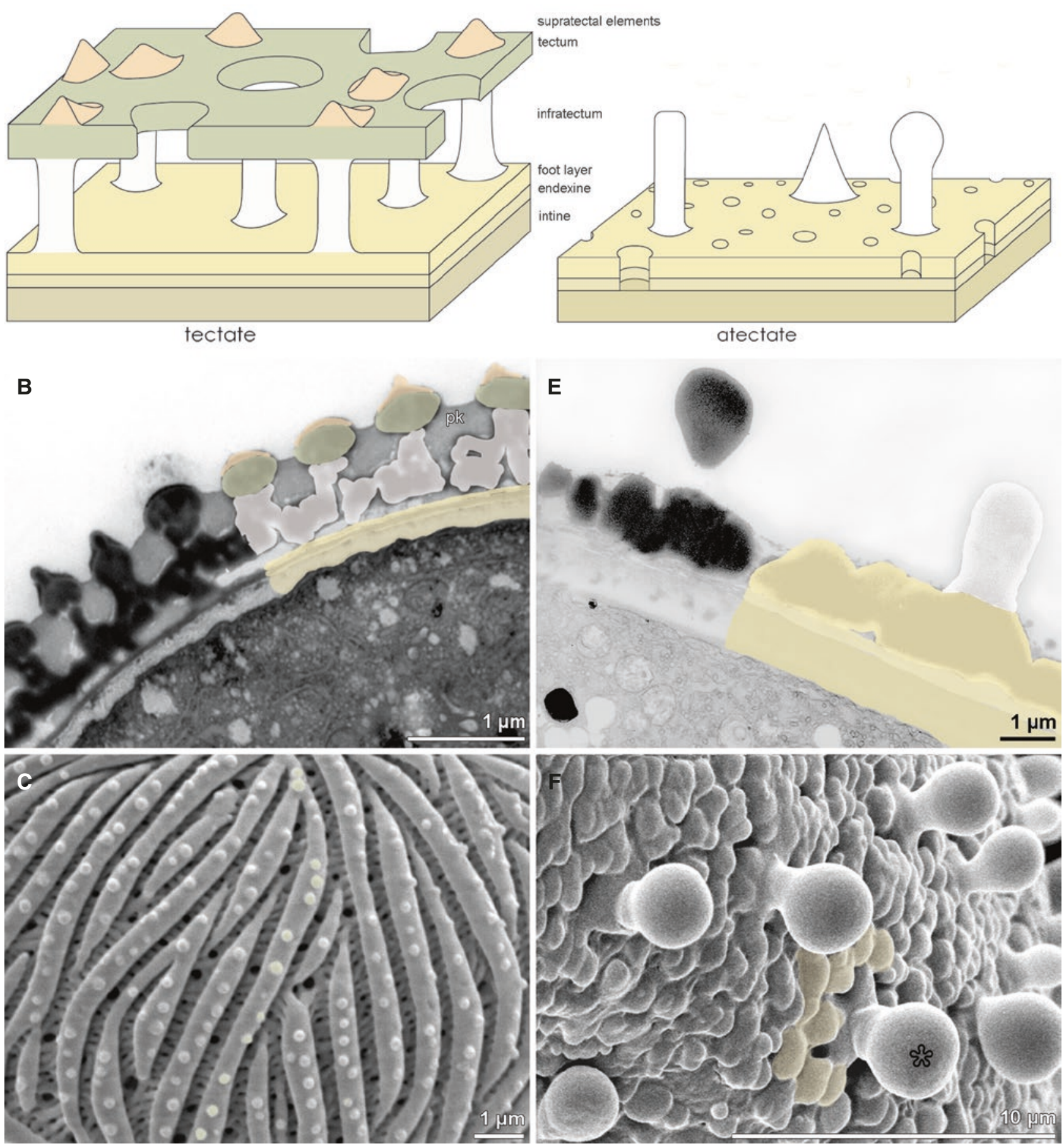

Fig. 16 Tectate vs atectate pollen wall. A-C. Tectate pollen wall. A. 3D-model. B. Saxifraga scardica, Saxifragaceae, cross section showing pollen wall stratification: tectum with internal tectum and supratectal elements, columellate infratectum, very thin footlayer, thin compact-continuous endexine, monolayered intine (colors refer to picture A), pk pollenkitt. C. Saxifraga scardica, Saxifragaceae, exine surface in SEM, sculpture striate with nanoechinate suprasculpture (colored). D-F. Atectate pollen wall. D. 3D-model. E. Iris pumila, Iridaceae, cross section showing pollen wall stratification: tectum and infratectum lacking, compact-continuous footlayer, monolayered intine (colors refer to picture D). F. Iris pumila, Iridaceae, exine surface (foot layer) in SEM, sculpture verrucate (colored) and clavate (asterisk)

decay as well as to chemical and mechanical damage (e.g., Steemans et al. 2010). However, in the environment, both biotic and abiotic factors are involved in pollen decomposition. Biotic factors are, for instance, the intrusion of bacteria and fungi (e.g., Elsik 1971; Havinga 1971, 1984; Skvarla et al. 1997; Phuphumirat et al. 2011). Abiotic factors include the pH-value of the substrate (e.g., Bryant and Hall 1993), 

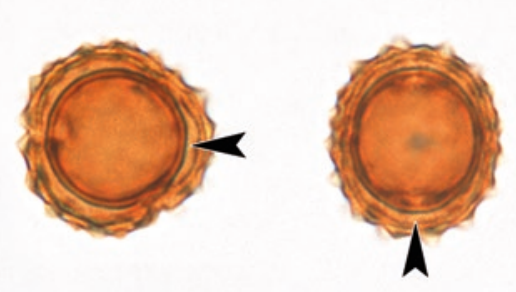

$10 \mu \mathrm{m}$

Fig. 17 Cavea. Xanthium spinosum, Asteraceae, acetolyzed pollen in polar (left) and equatorial (right) view showing exine cavity (cavea) between sexine and nexine (arrowheads)

oxidation/reduction (e.g., Twiddle and Bunting 2010), autoxidation by UV-light and oxygen (e.g., Jardine et al. 2015), destruction due to mechanic impact, water or fire (Cushing 1967; Bryant et al. 1994; Phuphumirat et al. 2011, 2015), and rapid changes in moisture levels (Halbritter and Hesse 2004).

The preservation status and the amount of pollen and spores in sediments depends on several factors, including rapid anaerobic burial and embedding in mud or peat, absence of any microbial destruction or sapropel, and the exclusion of oxygen (Klaus 1960, 1987; Playford and Dettmann 1996; Traverse 1988, 2007).

Recent studies on the composition of sporopollenin suggest that it may have two different types of chemical structures, oxygenated aromatic compounds and aliphatic compounds (e.g., Wiermann et al. 2001; Dobritsa et al. 2009; Gabarayeva and Grigorjeva 2010; Gabarayeva et al. 2010; Steemans et al. 2010; Colpitts et al. 2011). Although its exact structure remains unknown, sporopollenin is believed to compose oxidative polymers of carotenoids, polyunsaturated fatty acids, and conjugated phenols (Diego-Taboada et al. 2014). Some authors are using the plural form "sporopollenins," because there is evidence for several types of sporopollenin in ferns, gymnosperms, and angiosperms (Hemsley et al. 1993; de Leeuw et al. 2006). According to Diego-Taboada et al. (2014) sporopollenin in plants share a common aliphatic core, but depending on the taxon, contain different aromatic side chains. The chemical constitutional formula of sporopollenin is also unknown. The empirical formula of sporopollenin has highly variable amounts of $\mathrm{H}$ - and O-numbers. A generalized formula is $\mathrm{C}_{90} \mathrm{H}_{142} \mathrm{O}_{36}$ (Traverse 1988; Riding and KyffinHughes 2004).
The precise location of synthesis of sporopollenin precursors in tapetal cells and the mechanisms of secretion of sporopollenin monomers before polymerization in the microspore walls are still unclear, just as the processes involved in sporopollenin production at the cellular level (Lallemand et al. 2013). Liu and Fan (2013) reviewed the molecular regulation of sporopollenin biosynthesis, which probably includes a framework of catalytic enzyme reactions. As shown in the study by Colpitts et al. (2011), genes responsible for sporopollenin biosynthesis in Arabidopsis lead to the conclusion, that the pathway of sporopollenin biosynthesis seems well conserved in land plants since nearly 500 mya.

The question if sporopollenin is of sporophytic or gametophytic origin is still controversial. Probably both sources are involved. Most authors agree that sporopollenin is predominantly produced by the tapetum (Pacini and Franchi 1991; Blackmore et al. 2000; Wallace et al. 2015; Ariizumi and Toryama 2011; Quilichini et al. 2014).

The investigation of fossil pollen and spores revealed that fossilized sporopollenin appears chemically very different to sporopollenin found in modern plants (Fraser et al. 2011). During fossilization (coalification) and by diagenetic processes the chemical composition of sporopollenin is modified. Especially at high temperatures, above $200{ }^{\circ} \mathrm{C}$, sporopollenin undergoes a series of chemical changes (Yule et al. 2000; Fraser et al. 2014).

Sporopollenin biochemistry appears to have remained relatively stable since at least the Middle Pennsylvanian (approx. 310 mya). Fraser et al. (2012, 2014) postulated that the structure of sporopollenin has remained constant since plants invaded land during the Middle Ordovician (470-458 mya). A recent comprehensive review on sporopollenin and other biopolymers (de Leeuw et al. 2006) suggests that there may have been multiple forms and configurations of sporopollenin over geological time.

The sporopollenin wall is regarded as a synapomorphy in land plants and allowed land dispersal during the Silurian, perhaps already during the Middle Ordovician (Rubinstein et al. 2010; Wellman 2010).

\section{Chemically Related Biomacromolecules}

Sporopollenin is not unique in pollen/spore walls. Cell walls of some algae and dinoflagellates may contain chemically related biomacromolecules, named algaenan and dinosporin (Versteegh et al. 2012; Bogus et al. 2012). Like sporopollenin these resistant biomacromolecules may also fossilize. They have been reported in, e.g., Chlorella (He et al. 2016), Spirogyra (Simons et al. 1983), and Coleochaete (Ueno 2009). Furthermore, "sporopollenin-like" biomacromolecules have 
been found in megaspores and "massulae" of water ferns (Salviniales) (van Bergen et al. 1993), as well as in fruiting bodies of cellular slime molds (Maeda 1984).

\section{The Angiosperm Pollen Wall}

In angiosperms the ektexine consists in general of tectum, infratectum, and foot layer. The outer layer, the more-or-less continuous tectum, can be covered by supratectal elements. The infratectum beneath is columellate or granular (a second layer of columellae may form an internal tectum). However, as, e.g., Doyle (2005) has pointed out intermediate conditions are common. Even the alveolate infratectum, that by definition is restricted to gymnosperms, can also be found in some angiosperms (see "lllustrated Pollen Terms"). The foot layer may be either continuous, discontinuous or absent. The endexine can be described as continuous or discontinuous, spongy or compact, overall present, in apertures only, or even completely absent. Some typical deviations of the wall thickness are termed: arcus, annulus, tenuitas (see "lllustrated Pollen Terms") and costa (a thickening of the nexine/ endexine bordering an endoaperture; Fig. 18).

\section{The Gymnosperm Pollen Wall}

The gymnosperms comprise cycads, Ginkgo, conifers and Gnetales. The basic stratification (ektexine, endexine, and intine) of the gymnosperm pollen wall is identical to that of angiosperms. Still, the gymnosperm pollen wall differs from that of an angiosperm by having (1) a lamellate endexine in mature pollen, and (2) an infratectum that is never columellate (Van Campo and Lugardon 1973). The infratectum is either alveolate or granular.

A special terminology applies to saccate pollen, i.e. in Pinaceae and Podocarpaceae (Fig. 19). Saccus is an exinous expansion forming an air sac, with an alveolate infratectum. Corpus is the central body of a saccate pollen grain. Cappa is the thick walled proximal face of the corpus. Leptoma in conifer pollen refers to a thinning of the pollen wall on the distal face, presumed to function as germination area. Most frequently, two sacci are present (e.g., Abies, Pinus, Picea; Pinaceae), in some taxa even three (Dacrycarpus, Microstrobus; Podocarpaceae), or only a single one (Tsuga; Pinaceae).

The function and evolutionary significance of saccate pollen have been subject of much confusion. The sacci of Pinaceae and Podocarpaceae are reported to play an aerodynamic role, thus being of adaptive significance for wind pollination (Schwendemann et al. 2007; Grega et al. 2013). In fact, their functional role is to float in a

\section{A}
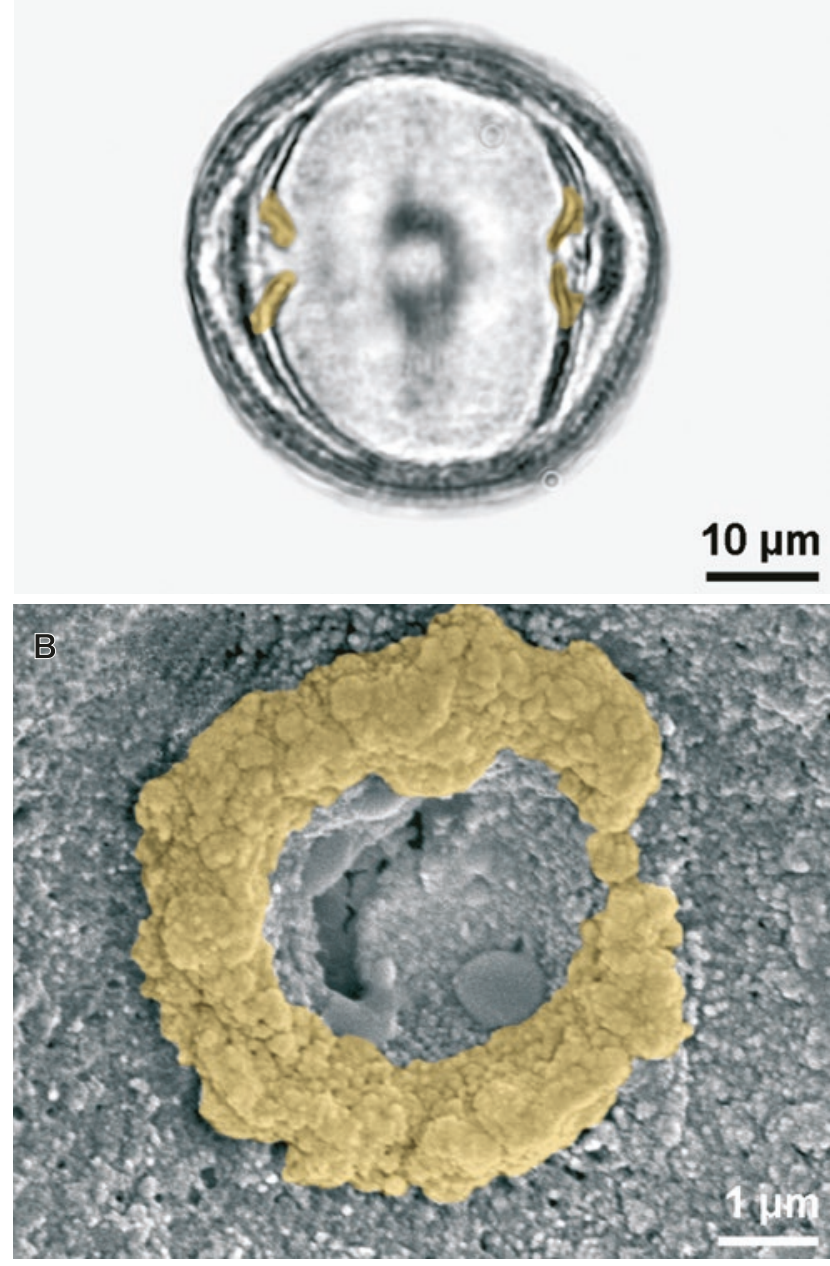

Fig. 18 Costa. A. Nyssa sp. Nyssaceae, fossil, middle Miocene, Austria, equatorial view (costa highlighted). B. Austobuxus nitidus, Picrodendraceae, view on the thickening around the endoaperture on the inner side of the wall

liquid pollination droplet towards the ovule ("flotation hypothesis" by Leslie 2010). The flotation system is interpreted as ancestral in conifers. The absence of sacci in, e.g., Cupressaceae and Taxaceae might reflect the loss of "drop mechanism," correlated with the change of pollination mode (shift to upwards orientation of the ovules) (Doyle 2010).

In Pinus, pollen can be grouped into two morphotypes (Fig. 20) of systematic value (Grímsson and Zetter 2011). The Pinus subgenus Strobus (haploxylon) type is characterized by pollen grains with broadly attached half-spherical air sacs-in LM the leptoma shows dotted thickenings (seen as dark spots). The Pinus subgenus Pinus (diploxylon) type is characterized by pollen grains with narrowly attached, spherical air sacs often with nodula on nexine area-the leptoma does not show any thickenings. 
A

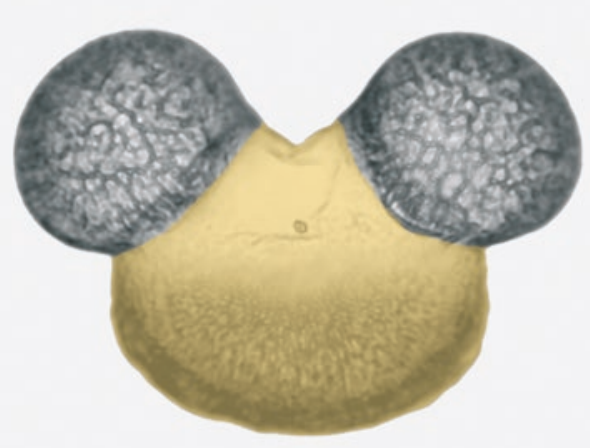

$100 \mu \mathrm{m}$

C

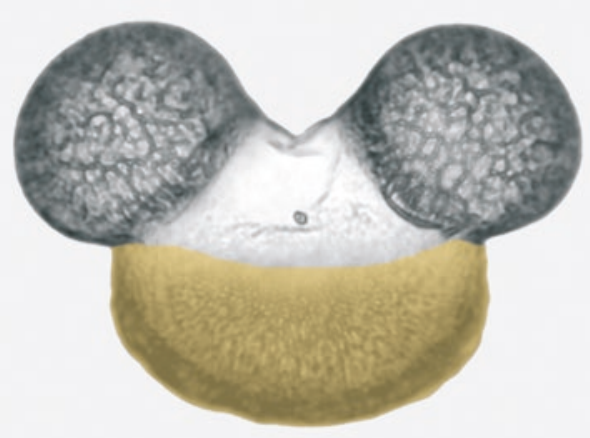

B

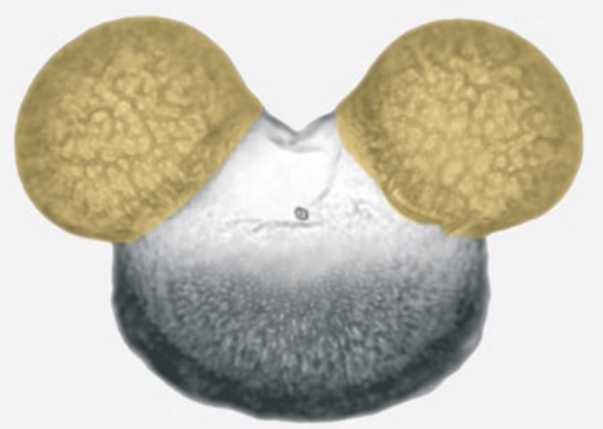

$100 \mu \mathrm{m}$

D

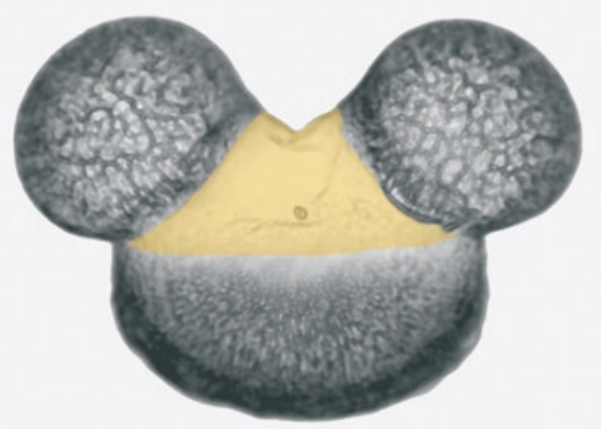

$100 \mu \mathrm{m}$

Fig. 19 Pollen terminology in saccate gymnosperm pollen. A-D. Abies sp., Pinaceae, bisaccate pollen, fossil, Quaternary, Austria, equatorial view. A. Corpus highlighted. B. Sacci highlighted. C. Cappa highlighted. D. Leptoma highlighted

\section{Sculpture: Ornamentation}

The terms ornamentation and sculpture applies to surface features of a pollen. The term sculpture is restricted by some authors to surface features in tectate pollen grains (e.g., Praglowski 1975; Punt et al. 2007). Sculpture elements (areola, clava, echinus, foveola, fossula, granulum, gemma, plicae, reticulum, rugulae, striae, verruca) can be extremely variable in both size and shape. Based on size many sculpture/ornamentation elements smaller than $1 \mu \mathrm{m}$ can be described with the prefix micro- $(1-0.5 \mu \mathrm{m})$ or nano- $(0.5-0.1 \mu \mathrm{m})$. Also, the boundary between two ornamentation types can be diffuse. For example, "gemmae" and "clavae" are very variable and sometimes hard to differentiate. Combinations of different sculpture/ornamentation elements are common, such as the combination reticulate and foveolate, or echinate and perforate. With a combined sculpture, the pollen ornamentation should then be described in a defined order, with the most eye-catching feature mentioned first, followed by the others. For example, Aristolochia pollen is verrucateperforate, as the verrucae are more prominent than the small perforations (Fig. 21). In the Caryophyllaceae, there are numerous, more-orless regularly arranged microechini and perforations. In some taxa the microechini are more prominent (microechinate-perforate), in others the perforations (perforate-microechinate) (Fig. 22). In case none of the features are eyecatching, the dominant feature might be a subjective decision of the palynologist e.g., in taxa, where two features are on a par (microechinate and perforate). A more complex example is Sanchezia nobilis (Acanthaceae, Fig. 23): is it plicate and reticulate? Should the rod-like elements 
A

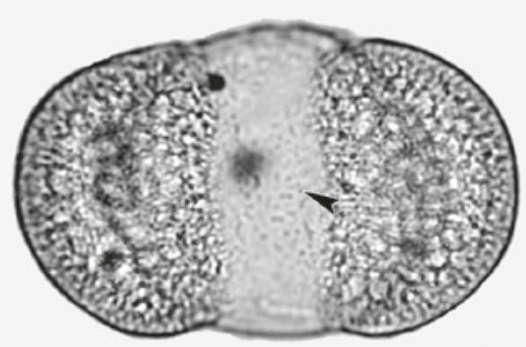

$10 \mu \mathrm{m}$

C

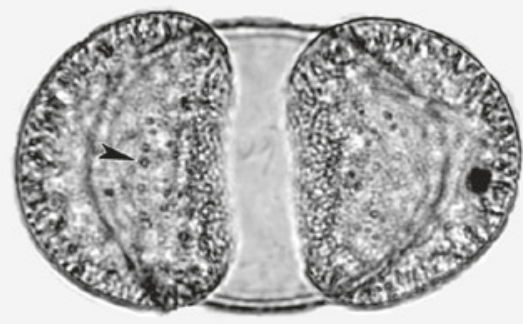

B

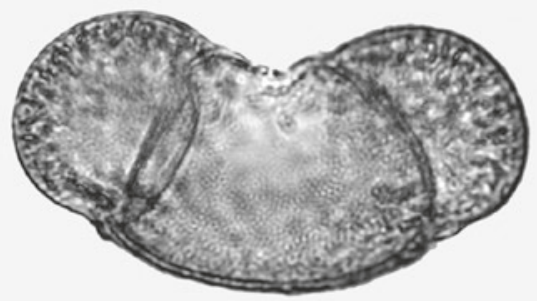

$10 \mu \mathrm{m}$

D

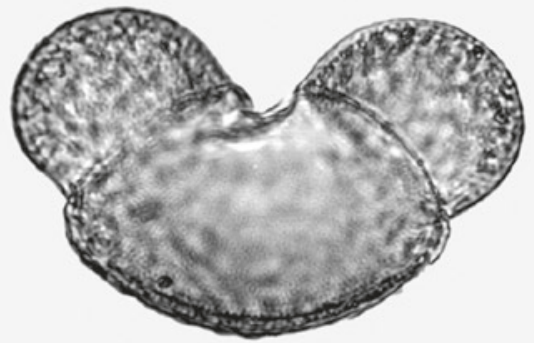

$10 \mu \mathrm{m}$

Fig. 20 Pollen types in saccate Pinus pollen (fossil, middle Miocene, Austria). A. Pinus subgenus Strobus (haploxylon), polar view, thickenings (arrowhead). B. Pinus subgenus Strobus (haploxylon), equatorial view. C. Pinus subgenus Pinus (diploxylon), polar view, nodula (arrowhead). D. Pinus subgenus Pinus (diploxylon), equatorial view
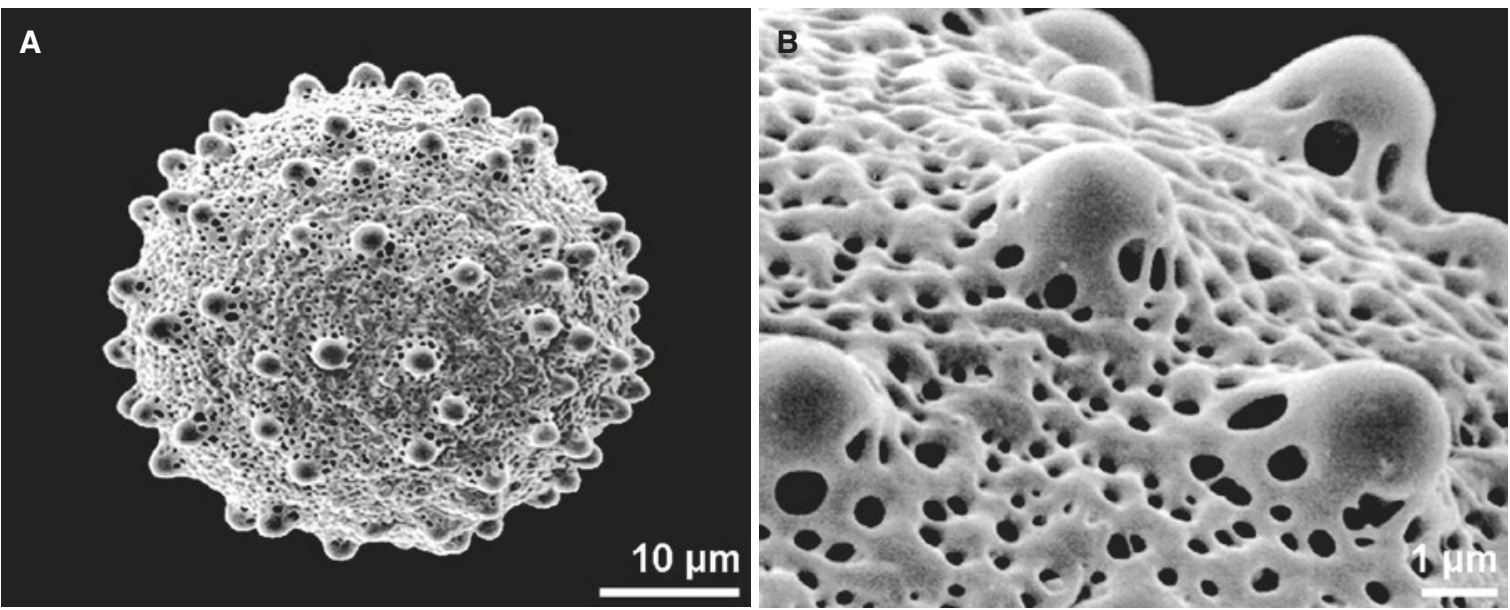

Fig. 21 Combined sculpture elements. A-B. Aristolochia arborea (Aristolochiaceae), verrucate, perforate

be termed clavae or free-standing columellae? Is the aperture a porus or a colporus? PalDat (www. paldat.org) might provide the answers?

Sculpture/ornamentation elements are often deviating and can be distributed regularly or irregu- larly over the pollen surface, restricted or absent from distinct areas (polar vs equatorial, interapertural vs aperture area; Fig. 24).

Ubisch bodies (orbicules) are sporopollenin elements produced by the tapetum. Ubisch bodies 
are usually found as isolated particles lining the mature locular wall, or between pollen grains (Huysmans et al. 1998; Halbritter and Hesse 2005; Vinckier et al. 2005; Verstraete et al. 2014). They often resemble the pollen wall ornamentation. In
Cupressaceae and Taxaceae, Ubisch bodies are considered part of the pollen ornamentation and are especially frequent on the leptoma of Cupressaceae (for examples, see "Illustrated Pollen Terms").
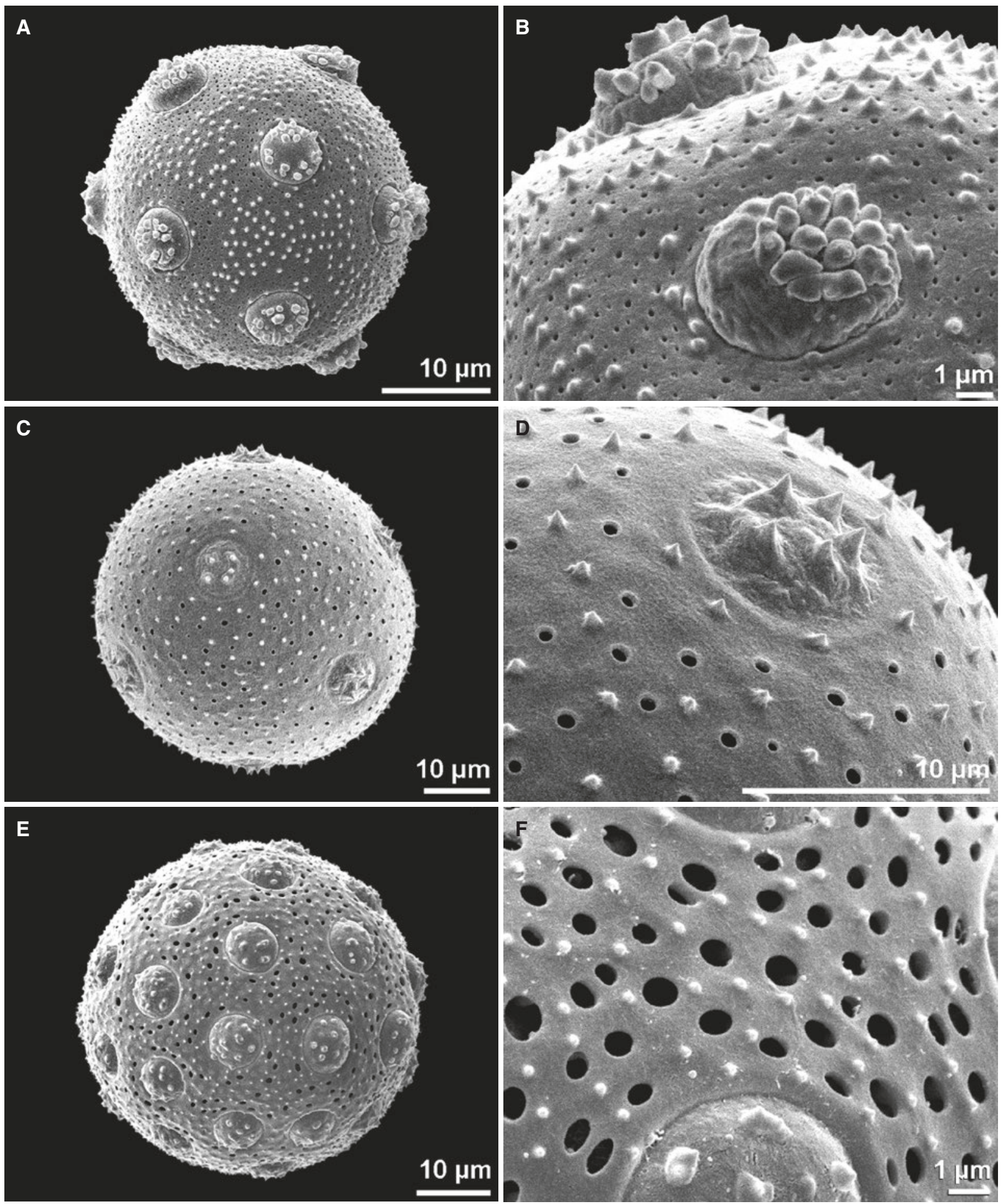

Fig. 22 Combined sculpture elements. A-B. Stellaria media, Caryophyllaceae, microechinate and perforate. C-D. Saponaria officinalis, Caryophyllaceae, microechinate and perforate. E-F. Silene succulenta, Caryophyllaceae, perforate and nanoechinate 

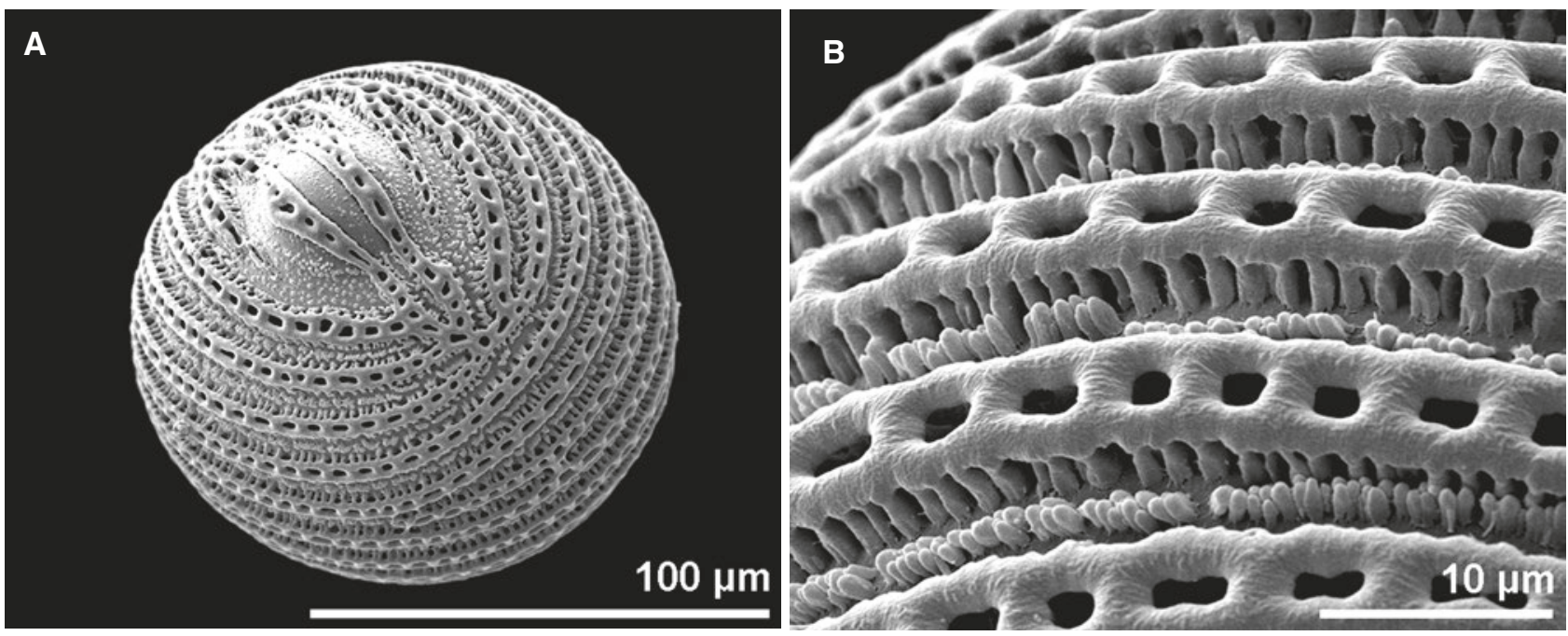

Fig. 23 Interpretation of sculpture elements. A-B. Sanchezia nobilis, Acanthaceae, oblique equatorial view and surface detail

\section{Ornamentation in LM vs. SEM}

An accurate description of pollen ornamentation depends on the optical magnification used and particularly on the point resolution. Even the SEM at low resolution may not be sufficient to distinguish pollen grains unequivocally (see "Methods in Palynology"). Depending on the type of microscope used for pollen analysis, some pollen features may remain hidden. For LM studies, the term scabrate is used, describing minute sculpture elements of undefined shape and size close to the resolution limit of the LM. For example, Juglans pollen is scabrate in LM as well as under low magnification SEM, but is nanoechinate at high resolution SEM (Fig. 25A-B).

The descriptive terms may differ whether LM or SEM is used and should be described for both. For example, UImus pollen seen in LM is described as verrucate. Using low SEM magnification the ornamentation is rugulate to verrucate (Fig. 25C-E). High SEM magnification shows additional granula $(\leq 0.1 \mu \mathrm{m})$.

Another example for different interpretations in LM VS SEM is the term psilate. Many pollen grains that appear psilate in LM show a distinct ornamentation using high SEM magnification. For example, pollen of Allium ursinum is psilate in LM, but is striate and perforate in SEM (Fig. 25F-G).

Terms with nano- or micro- can only be observed in SEM (see "Methods in Palynology"). For example, the term granulate should only be used when describing pollen ornamentation under SEM. When minute sculptural elements are observed under high resolution SEM, it is possible to distinguish real "granula" (sculpture element of different/indefinable shape, $\leq$ than $0.1 \mu \mathrm{m}$ ) from other nano- and/or micro-sculpture elements. For example, the allegedly granulate ornamentation of many Poaceae is in fact nanoechinate, the pointed ends of the echini are seen best in profile and not from top view (see "Illustrated Pollen Terms").

\section{Role of Pollen Ornamentation in Pollination}

Depending on the pollination mode the outer pollen wall may be either highly ornamented, often with plenty of pollen coatings (mainly pollenkitt; Pacini and Hesse 2005), or with a more or less psilate pollen surface. The pollen wall of zoophilous plants, as well as autogamous plants, is usually highly ornamented and the thick exine consists of high amounts of sporopollenin (Faegri and Iversen 1989). Pollen of anemophilous plants are known to have less ornamentation and less sporopollenin (Friedman and Barrett 2009). Usually psilate pollen in temperate and boreal zones is indicative for anemophily (Faegri and Iversen 1989), whereas in the tropics it is also indicative for zoophily (Furness and Rudall 1999). For example, in Aroideae (e.g., Montrichardia, Dieffenbachia, Philodendron, Gearum) psilate pollen usually equipped with pollenkitt is adapted for entomophily (Weber and Halbritter 2007).

\section{Functional Value of Exine Reduction}

Layers of the basic pollen wall type may vary and be partly or totally reduced (for examples, see 

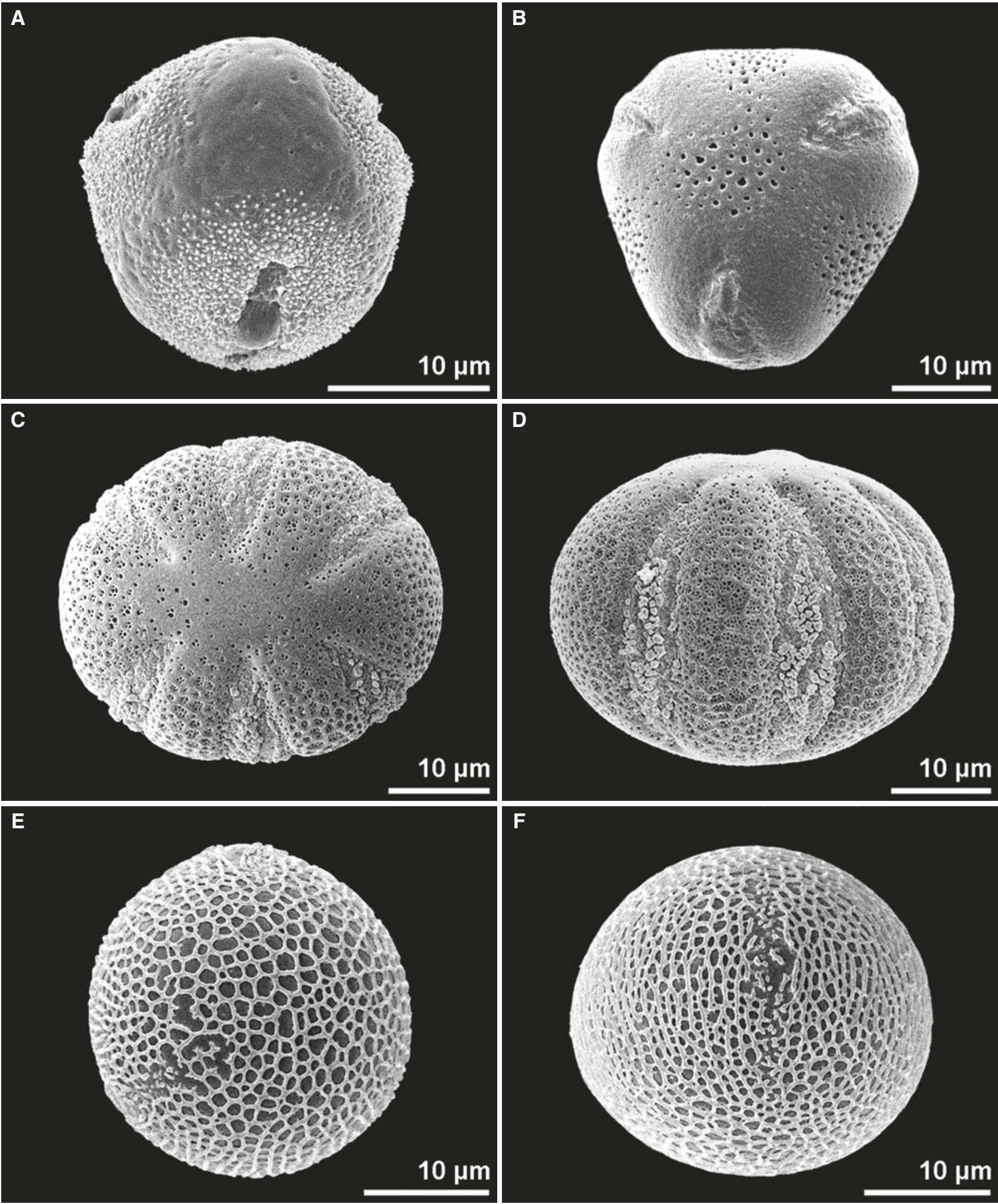

Fig. 24 Pollen surface variation. A. Fallopia convolvulus, Polygonaceae, polar view, polar area psilate to perforate and regions around apertures microechinate. B. Sideritis montana, Lamiaceae, polar view, polar and interapertural areas perforate to foveolate and regions around apertures psilate. C-D. Salvia austriaca, Lamiaceae, pollen bireticulate, except psilate polar areas (polar and equatorial view). E-F. Solandra longiflora, Solanaceae, polar area reticulate, equatorial region striato-reticulate (polar and equatorial view) 


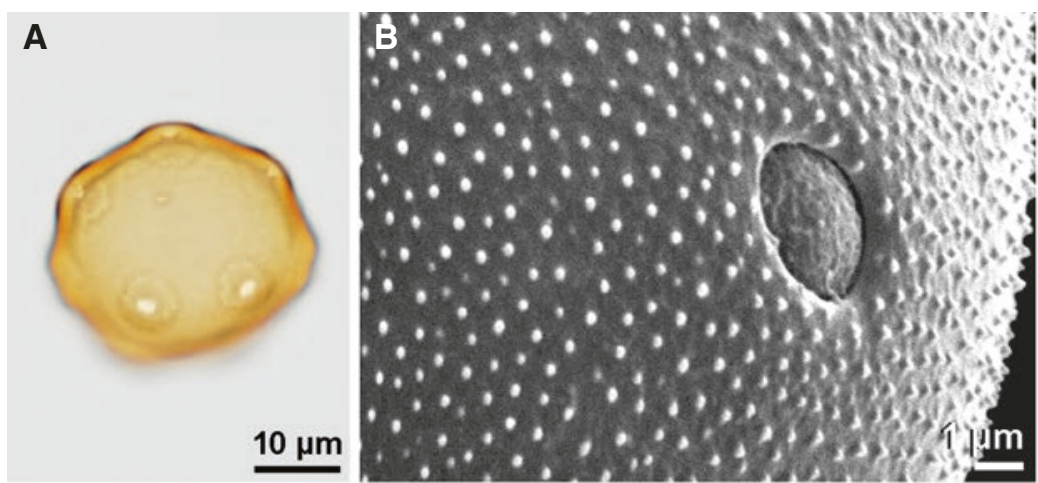

\section{C}
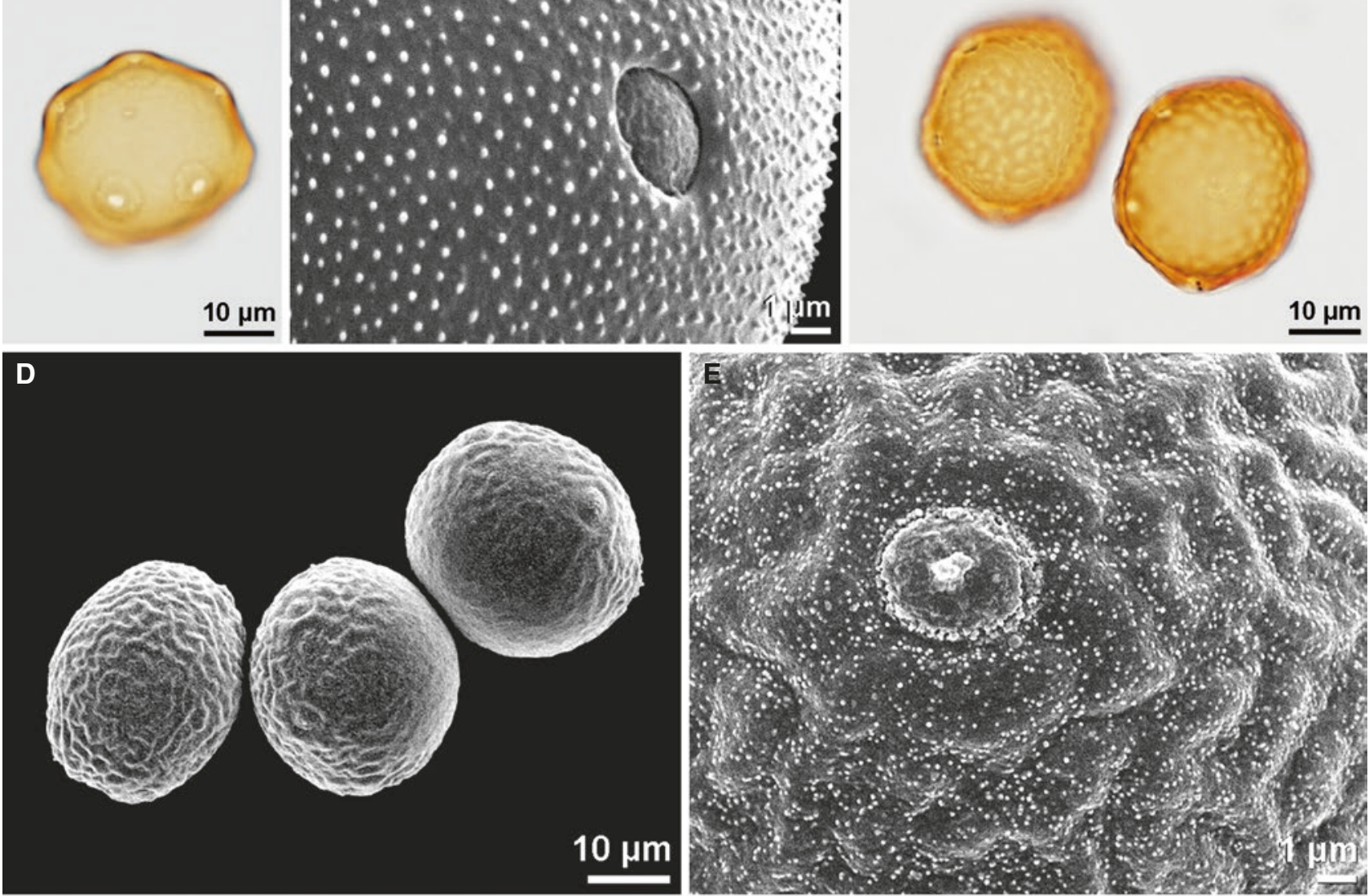

$\mathbf{F}$

G

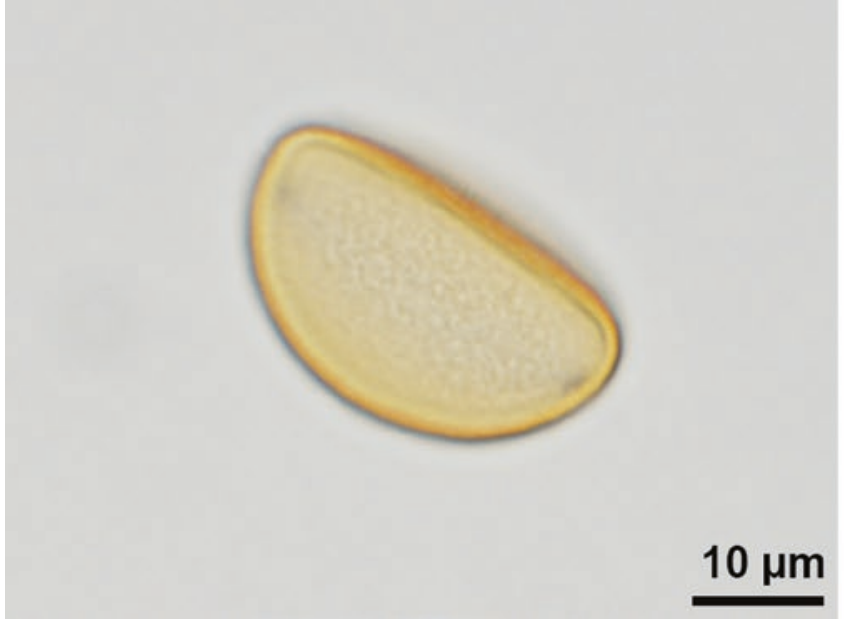

$10 \mu \mathrm{m}$

$10 \mu \mathrm{m}$

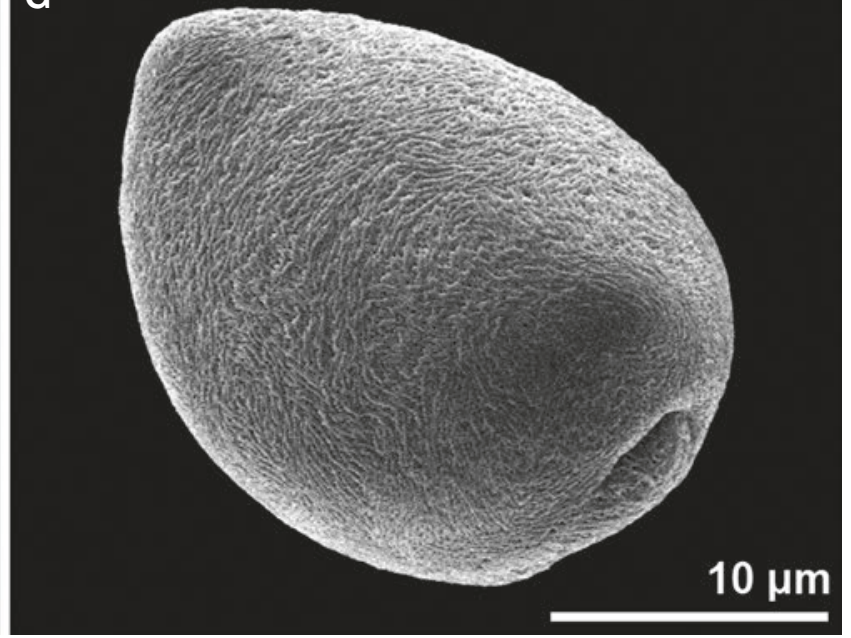

Fig. 25 Ornamentation in LM vs SEM. A-B. Juglans sp., Juglandaceae. A. Scabrate to psilate, LM. B. Nanoechinate, SEM. C-E. Ulmus laevis, Ulmaceae. C. Rugulate, LM. D. Rugulate to verrucate, low magnification, SEM. E. Verrucate, granulate, high magnification SEM. F-G. Allium ursinum, Amaryllidaceae. F. Psilate to scabrate, LM. G. Rugulateperforate, low magnification, SEM

"Pollen Wall" in "lllustrated Pollen Terms"). The sporopollenin ektexine is lacking e.g., in some genera of Monimiaceae and Lauraceae (Walker 1976), in the aquatic Ceratophyllaceae (Takahashi 1995), in many genera of Aroideae, and in the inaperturate filiform pollen of seagrasses, Posidonia. An absent exine is an adaptation to hydrophily and correlated with, e.g., aquatic habits, anemophily, and pollinia (Furness 2007). Interestingly, exine reduction has evolved iteratively in angiosperms, especially 
throughout the monocots. Orchidaceae, Asclepiadaceae, Mimosaceae, Annonaceae, and other families often produce compound pollen, where usually only the outermost pollen wall show the typical ektexine structure with tectum and columellae. Pollen grains within calymmate polyads or tetrads have extremely reduced and fragile pollen walls, that probably facilitates pollen germination (Knox and McConchie 1986). The extreme exine reduction in many orchid pollinia seems also to correlate with pollen germination (Johnson and Edwards 2000).

\section{Harmomegathy: The Harmomegathic Effect}

$\mathrm{P}$ ollen grains are able to absorb and release water (+ various liquids); thus, each pollen grain exists in two morphologically different conditions, dry and hydrated (Fig. 26). Harmomegathic mechanisms, e.g., infolding of the pollen wall (Rowley and Skvarla 2000), accommodate the change of the osmotic pressure in the cytoplasm during hydration or dehydration. These mechanisms are denoted as harmomegathic effect, also known as Wodehouse effect. The main purpose of the harmomegathic effect is to protect the male gametophyte against desiccation during pollen presentation and dispersal, and is often related to pollination biology.

In mature anthers, pollen is turgescent before shedding. After anther dehiscence and during pollen presentation, water loss takes place and the pollen grain becomes typically infolded. Various pollen wall features are involved in the harmomegathic effect:

- Position, number, and type of apertures: the most important features

- Thinned or thickened regions within the pollen wall: in particular, internal belts or endoapertures. If the ektexine is considerably reduced, its role is taken over by other wall strata, namely, by a thick endexine or intine. On the other hand, if the exine is extremely rigid, then the harmomegathic effect is only marginal

- Ornamentation type

- Pollen size: small, thin-walled pollen grains which are usually less infolded

- Pollen coatings: if abundant, pollen coatings have an insulating influence that reduces the harmomegathic effect

The combination of these features is influencing the mode of infolding. Terms used for common morphotypes of dry pollen include: apertures sunken, boatshaped, cup-shaped, interapertural area infolded, irregularly infolded, not infolded. In addition, the pollen shape can be described with terms that might be helpful for an adequate description such as barrel-like, disk-like, or kidney-like. The mode of infolding and/or shape of pollen in dry condition may be typical for a family and/or genus and therefore of systematic relevance (see "Palynology History and Systematic Aspects").

The harmomegathic effect is also observed in pollen taken from herbarium material, and to some degree in fossil material (Halbritter and Hesse 2004). This effect is to some degree reversible: rehydrated pollen at the stigma, or under laboratory conditions (various liquids), is again turgescent and largely recalls the shape before shedding. A second dehydration does not necessarily result in the typical dry shape but, if pollen walls are sufficiently stable, the harmomegathic effect can be induced several times in the same way. In pollen with thin walls, the susceptible internal structure may become damaged, and the harmomegathic effect may result in different and randomly shaped pollen. Infoldings of the pollen wall after acetolysis treatment are mostly not comparable with those observed in dry condition.

\section{Size}

$D$ ollen size varies from less than $10 \mu \mathrm{m}$ to more than $100 \mu \mathrm{m}$ (Fig. 27). To indicate pollen size the largest diameter is used (Hesse et al. 2009). The size depends on the degree of hydration and the preparation method (Reitsma 1969, see also "Methods in Palynology"). Because of this and natural variation, a range categorizing pollen size is recommended: very small $(<10 \mu \mathrm{m})$, small (10$25 \mu \mathrm{m})$, medium $(26-50 \mu \mathrm{m})$, large $(51-100 \mu \mathrm{m})$, and very large $(>100 \mu \mathrm{m})$.

\section{Heterostyly and Pollen Dimorphism}

In heterostylous (long-styled and short-styled) species two different pollen types occur, where pollen size and number of apertures or the ornamentation may differ. In Linum flavum (Linaceae) pollen of the short-styled morph is baculate, and the long-styled morph clavate (Fig. 28). In Primula veris (Primulaceae) the pollen of the short-styled morph is larger and has more apertures than pollen of the long-styled morph (Fig. 29A). In the tristylous species Lythrum salicaria 

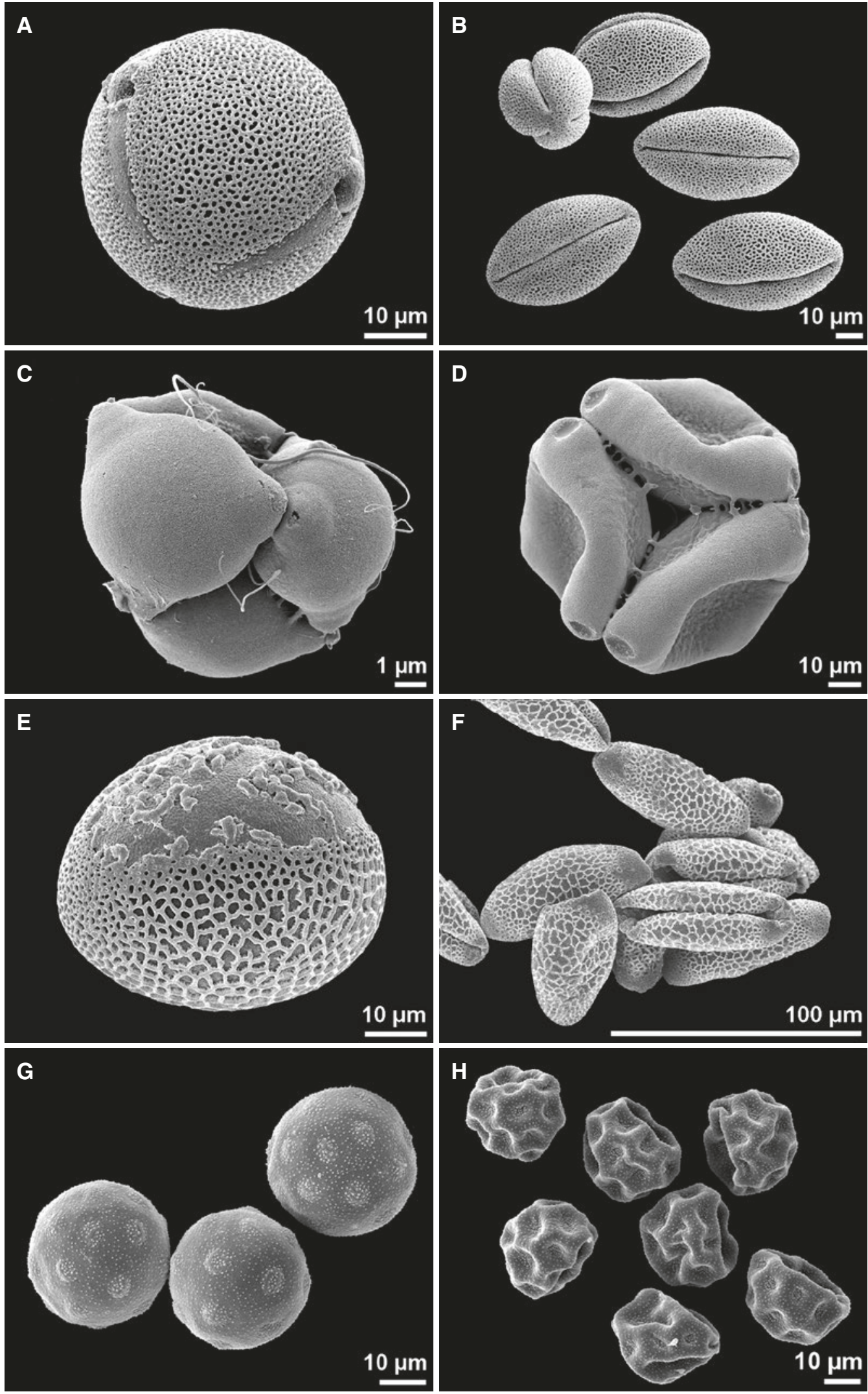

Fig. 26 Harmomegathic effect-hydrated vs dry pollen. A-B. Cistus creticus, Cistaceae. A. Spheroidal, outline circular. B. Prolate, outline lobate, apertures infolded. C-D. Epilobium palustre, Onagraceae, tetrad. C. Oblate, outline triangular. D. Interapertural area sunken. E-F. Vriesea pabstii, Bromeliaceae. E. Oblate, outline elliptic. F. Boat-shaped. G-H. Alisma lanceolatum, Alismataceae. G. Spheroidal, outline circular. H. Irregularly infolded 


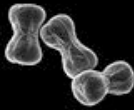

Myosotis scorpioides

\section{Boraginaceae}

very small $(<10 \mu \mathrm{m})$

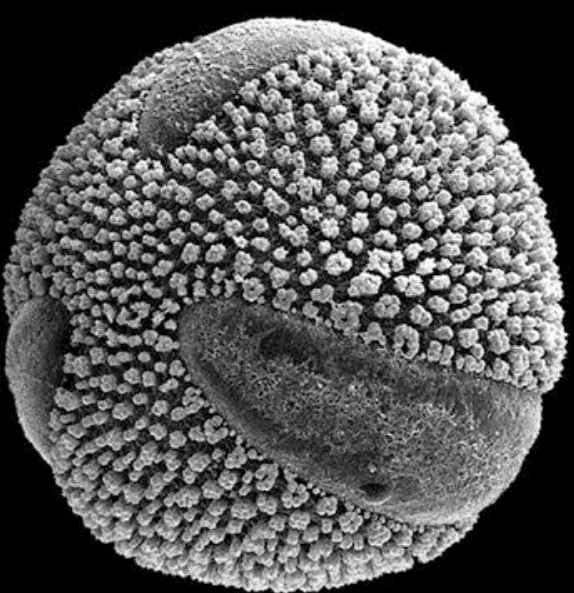

Plumbago auriculata

Plumbaginaceae large $(50-100 \mu \mathrm{m})$

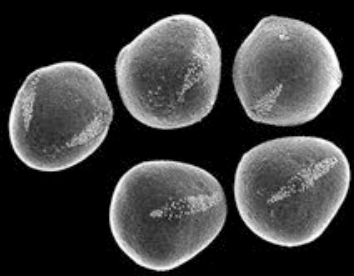

Alkanna orientalis

Boraginaceae small $(10-25 \mu \mathrm{m})$

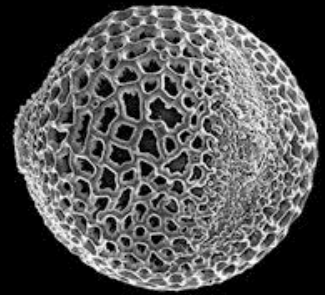

Syringa vulgaris

Oleaceae

medium (25 - 50 m)

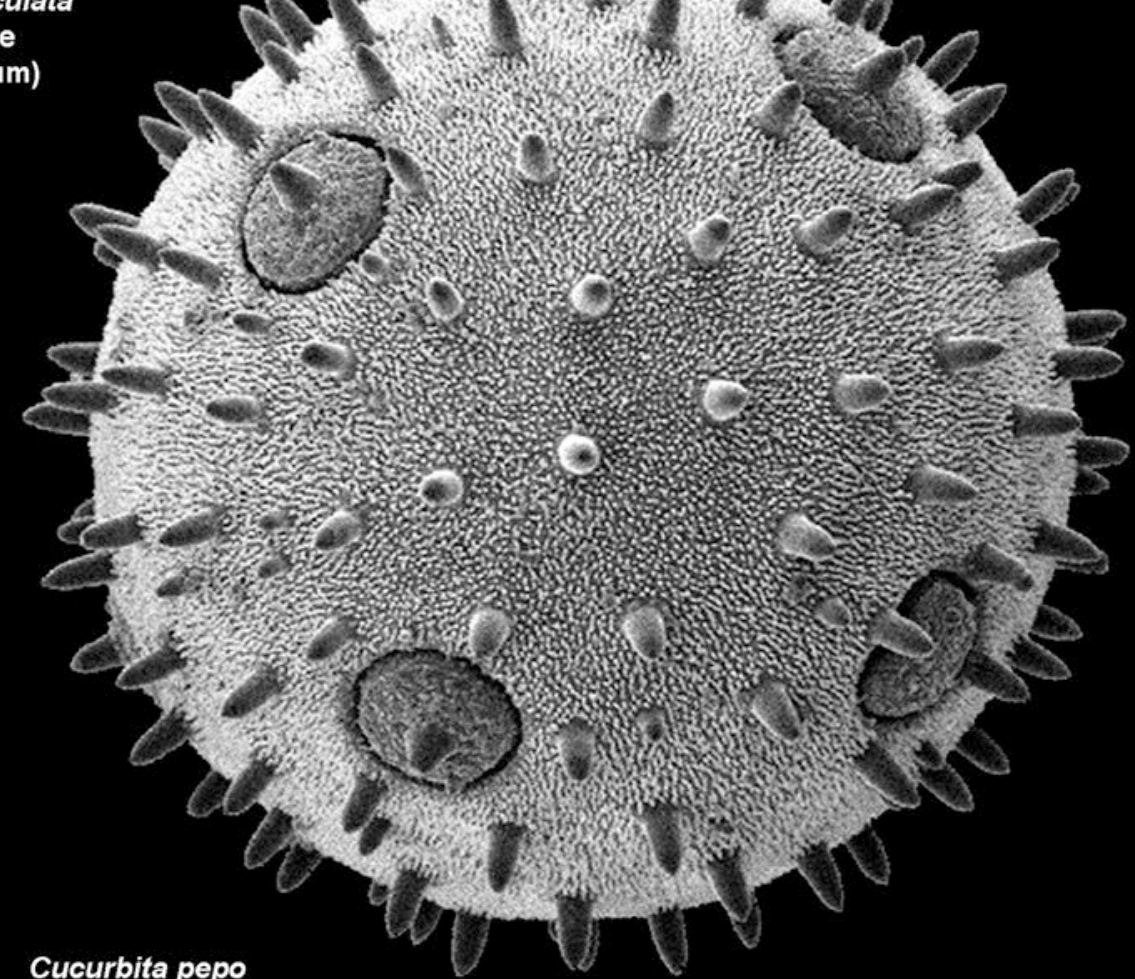

Cucurbitaceae

very large $(>100 \mu \mathrm{m})$

Fig. 27 Pollen size categories. 

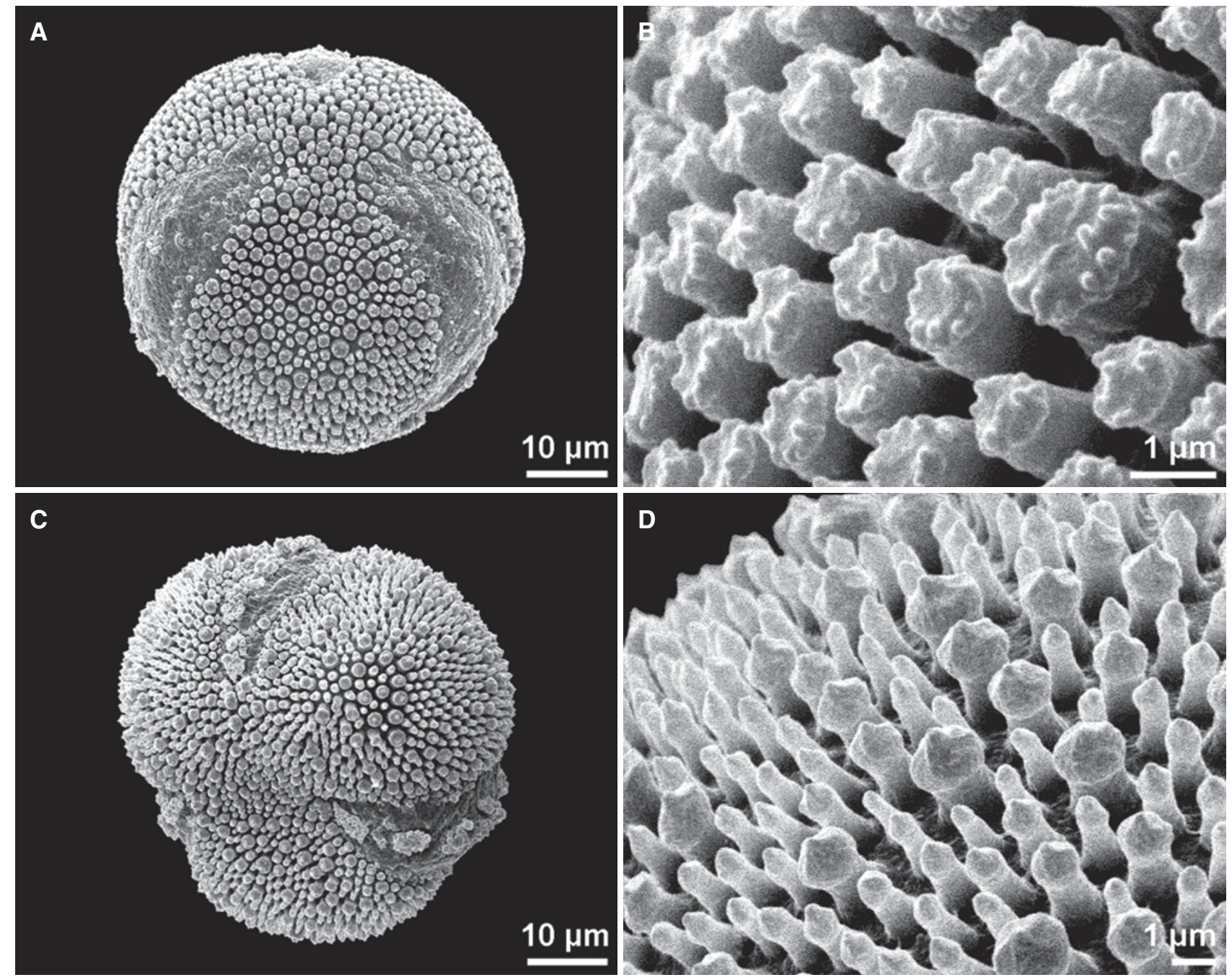

Fig. 28 Pollen dimorphism - different ornamentation. A-D. Linum flavum, Linaceae, (A-B) short-styled morph, baculate, (B-C) long-styled morph, clavate
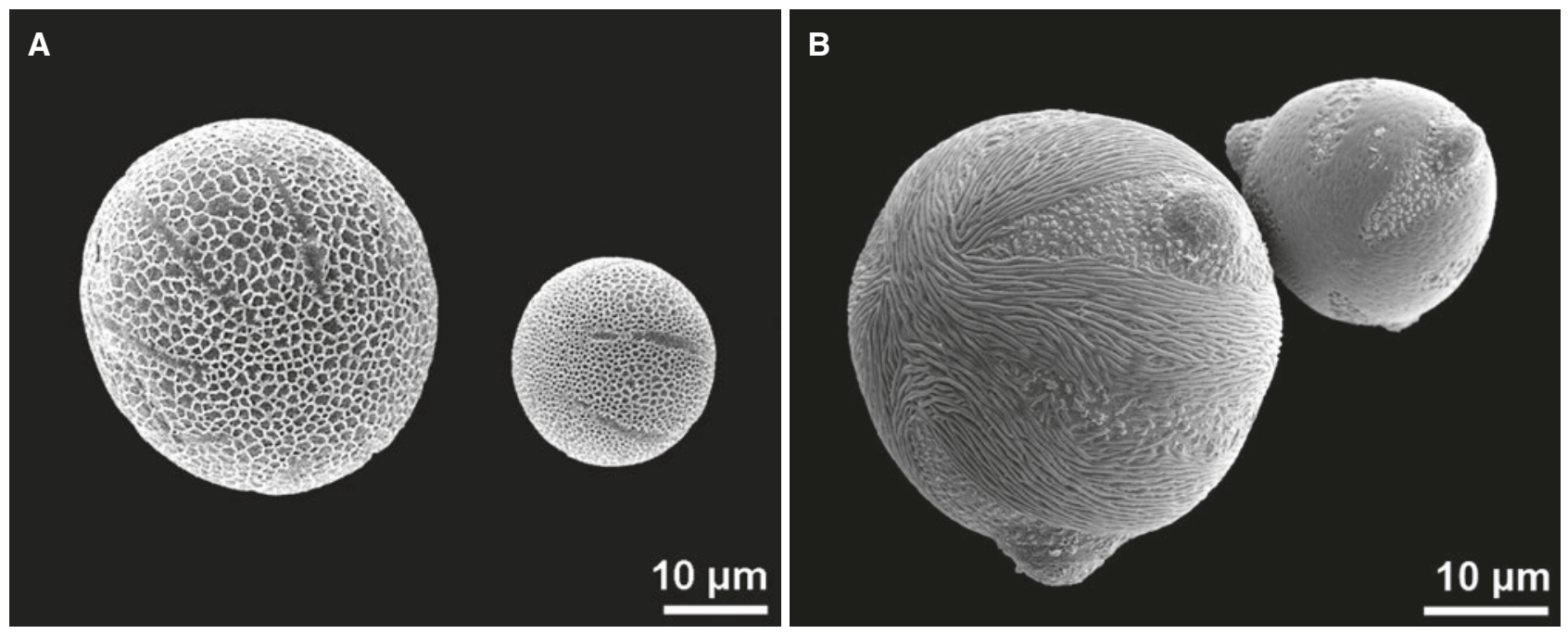

Fig. 29 Pollen dimorphism - different size. A. Primula veris, Primulaceae, short-styled morph (left), long-styled morph (right). B. Lythrum salicaria (Lythraceae), medium-styled morph, dimorphic pollen 

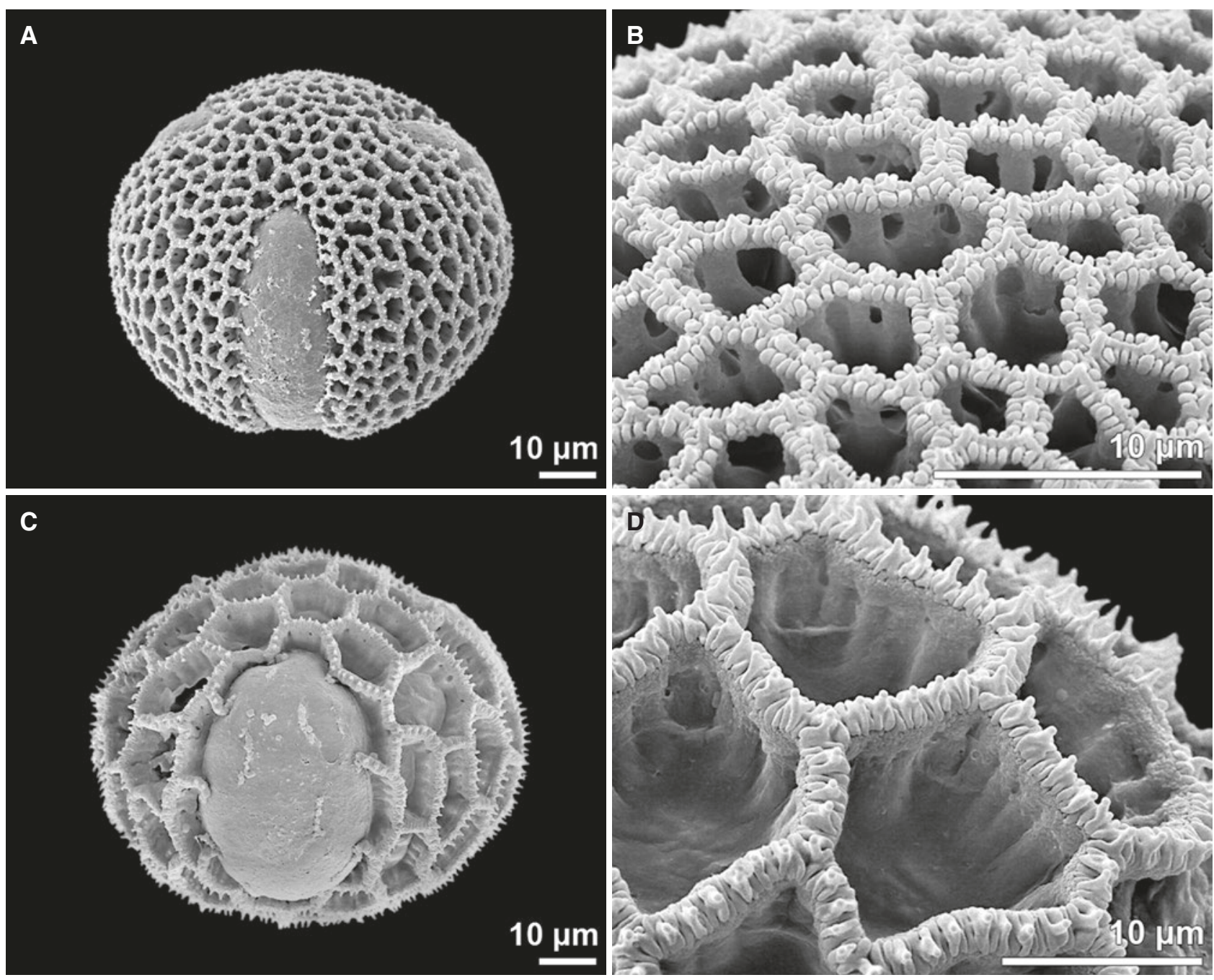

Fig. 30 Pollen dimorphism - different ornamentation. A-D. Armeria alpina, Plumbaginaceae. A-B. Morph 1, reticulate. C-D. Morph 2, reticulate

(Lythraceae) pollen is dimorphic, with different size, ornamentation, and even color of the pollen grains (blue and yellow). Pollen of the long-styled morph is small sized (about $20 \mu \mathrm{m}$ ), short styled morph is medium sized (about $35 \mu \mathrm{m}$ ) and medium-styled morph is small to medium sized (within a single anther) (Fig. 29B). In some Plumbaginaceae, for example in distylous species of Armeria, pollen dimorphism (reticulate, different size of lumina and suprasculpture elements) is correlated with dimorphic stigmatic papillae, but style and stamen lengths are monomorphic (Ganders 1979; Fig. 30).

\section{Aberrant Pollen Grains}

A berrant pollen grains are often ignored but occur regularly in small percentages in nearly all anthers and may vary from one individual to another (Pozhidaev 2000a, b; Banks et al. 2007). These aberrant pollen grains can differ from the typical pollen type of the species in shape and dimension, in number and arrangement of apertures, and in ornamentation type (Fig. 31). Reasons for the production of deviating pollen forms are genetically (polyploidy), 

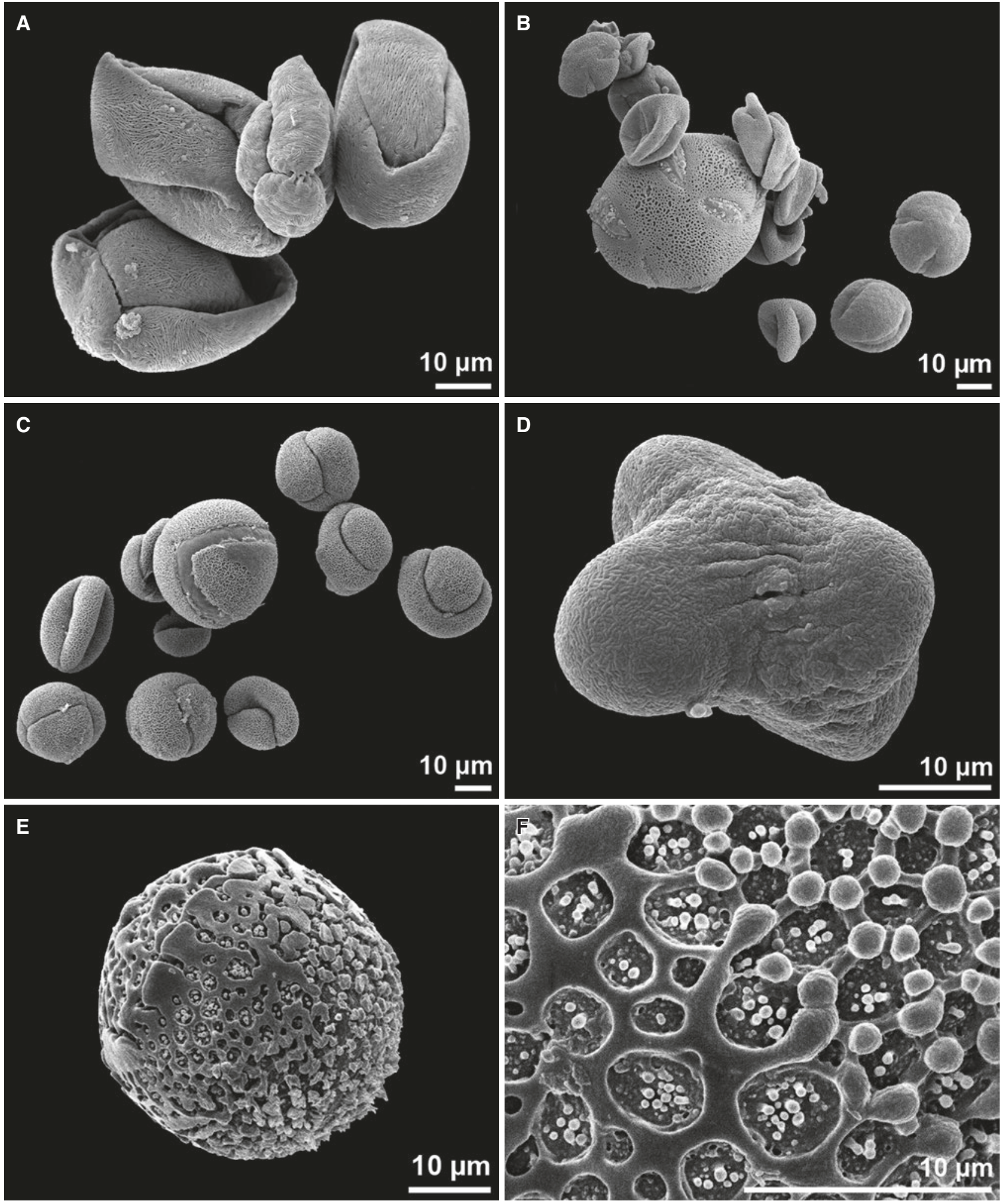

Fig. 31 Aberrant pollen grains. A. Malus sieboldii, Rosaceae, irregular aperture arrangement (usually tricolporate). B. Oxalis sp., Oxalidaceae, many aborted pollen grains, giant pollen (usually tricolpate). C. Scaevola sp., Goodeniaceae, pollen varies in size and aperture arrangement. D. Scandix pecten-veneris, Apiaceae, "double" pollen grain (usually tricolporate). E. Codiaeum-hybrid, Euphorbiaceae, ornamentation intermediate between parent plant species e.g., croton pattern and reticulate with free-standing columellae. F. Codiaeum-hybrid, Euphorbiaceae, surface detail 
chemically, or environmentally induced. Such deviating, malformed pollen is frequently found in cultivated plants, ornamental plants, agricultural crops, annual plants, plants with asexual reproduction (autogamic plants, apomicts), and hybrids. Some species of apomicts, agricultural crops or cultivated plants (e.g., Malus sieboldii) produce only malformed pollen.

\section{References}

Ariizumi T, Toryama K (2011) Genetic regulation of sporopollenin synthesis and pollen exine development. Annu Rev Plant Biol 62: 437-460

Banks H, Stafford P, Crane PR (2007) Aperture variation in the pollen of Nelumbo (Nelumbonaceae). Grana 46: 157-163

Blackmore S, Barnes SH (1995) Garside's rule and the microspore tetrads of Grevillea rosmarinifolia A. Cunningham and Dryandra polycephala Bentham (Proteaceae). Rev Palaeobot Palynol 85: 111 1-121

Blackmore S, Cannon SM (1983) Palynology and systematics of Morinaceae. Rev Palaeobot Palynol 40: 207-226

Blackmore S, Takahashi M, Uehara K (2000) A preliminary phylogenetic analysis of sporogenesis in pteridophytes. In: Harley MM, Morton CM, Blackmore S (eds) Pollen and spores: morphology and biology. Royal Botanic Gardens, Kew, p. 109-124

Bogus K, Harding IC, King A, Charles AJ, Zonneveld KAF, Versteegh GJM (2012) The composition and diversity of dinosporin in species of the Apectodinium complex (Dinoflagellata). Rev Palaeobot Palynol 183: 21-31

Braconnot H (1829) Recherches chimiques sur le pollen du Typha latifolia, Lin., famille de typhacées. Ann Chim Phys 42: 91-105

Bryant VM, Hall SA (1993) Archaeological palynology in the United States: A critique. Am Antiquity 58: 277-286

Bryant VM, Holloway RG, Jones JG, Carlson DL (1994) Pollen preservation in alkaline soils of the American southwest. In: Traverse A (ed) Sedimentation of organic particles. Cambridge University Press, Cambridge, New York, Melbourne, Madrid, Cape Town, Singapore, Sao Paolo, p. 47-58

Colpitts CC, Kim SS, Posehn SE, Jepson C, Kim SY, Wiedemann G, Reski R, Wee AGH, Douglas CJ, Suh D-Y (2011) PpASCL, a moss ortholog of anther-specific chalcone synthase-like enzymes, is a hydroxyalkylpyrone synthase involved in an evolutionarily conserved sporopollenin biosynthesis pathway. New Phytol 192: 855-868

Copenhaver GP (2005) A compendium of plant species producing pollen tetrads. J North Carolina Acad Sci 12: 17-35

Cushing EJ (1967) Evidence for differential pollen preservation in late Quaternary sediments in Minnesota. Rev Palaeobot Palynol 4: 87-101

De LeeuW JW, Versteegh GJM, Van Bergen PF (2006) Biomacromolecules of algae and plants and their fossil analogues. Plant Ecology 182: 209-233

Diego-Taboada A, Beckett ST, Atkin SL, Mackenzie G (2014) Hollow pollen shells to enhance drug delivery. Pharmaceutics 6: 80-96

Dobritsa AA, Shrestha J, Morant M, Pinot F, Matsuno M, Swanson R, Lindberg Møller B, Preuss D (2009) CYP704B 1 is a Long-Chain Fatty Acid v-Hydroxylase essential for sporopollenin synthesis in pollen of Arabidopsis. Plant Physiol 151: 574-589

Doyle J (2005) Early evolution of angiosperm pollen as inferred from molecular and morphological phylogenetic analyses. Grana 44: 227-251

Doyle JA (2010) Function and evolution of saccate pollen. New Phytol 188: 6-9

Elsik WC (1971) Microbial degradation of sporopollenin. In: Brooks J, Grant PR, Muir MD, Van Gijzel P, Shaw G (eds) Sporopollenin. Academic Press, London New York, p. 480-511

Faegri K, Iversen J (1989) Textbook of Pollen analysis. $4^{\text {th }}$ edition, John Wiley \& Sons, Chichester

Fraser WT, Scott AC, Forbes AES, Glasspool IJ, Plotnick RE, Kenig F, Lomax BH (2012) Evolutionary stasis of sporopollenin biochemistry revealed by unaltered Pennsylvanian spores. New Phytol 196: 397-401

Fraser WT, Sephton MA, Watson JS, Self S, Lomax BH, James DI, Wellman $\mathrm{CH}$, Callaghan TV, Beerling DJ (2011) UV-B absorbing pigments in spores: biochemical responses to shade in a high-latitude birch forest and implications for sporopollenin-based proxies of past environmental change. Polar Res 30, 8312, https://doi.org/10.3402/polar.v30o0.8312

Fraser WT, Watson JS, Sephton MA, Lomax BH, Harrington G, Gosling WD, Self S (2014) Changes in spore chemistry and appearance with increasing maturity. Rev Palaeobot Palynol 201: 41-46

Friedman J, Barrett SCH (2009) Wind of change: new insights on the ecology and evolution of pollination and mating in wind-pollinated plants. Ann Bot 103: 1515-1527

Furness CA (2007) Why does some pollen lack apertures? A review of inaperturate pollen in eudicots. Bot J Linn Soc 155: 29-48

Furness CA, Rudall PJ (1999) Microsporogenesis in Monocotyledons. Ann Bot 84: 475-499

Furness CA, Rudall PJ (2001) Pollen and anther characters in monocot systematics. Grana 40: 17-25

Furness CA, Rudall PJ (2003) Apertures with lids: distribution and significance of operculate pollen in Monocotyledons. Int J Plant Sci 164: 835-854

Gabarayeva NI, Grigorjeva VV (2010) Sporoderm ontogeny in Chamaedorea microspadix (Arecaceae): selfassembly as the underlying cause of development. Grana 49: 91-114

Gabarayeva NI, Grigorjeva VV, Rowley JR (2010) A new look at sporoderm ontogeny in Persea americana and the hidden side of development. Ann Bot 105: 939-955

Ganders FR (1979) The biology of heterostyly. NZ J Bot 17(4): 607-635

Grega L, Anderson S, Cheetham M, Clemente M, Colletti A, Moy W, Talarico D, Thatcher SL, Osborn JM (2013) Aerodynamic characteristics of saccate pollen grains. Int J Plant Sci 174: 499-510

Grímsson F, Zetter R (2011) Combined LM and SEM study of the Middle Miocene (Sarmatian) palynoflora from the Lavanttal Basin, Austria: Part II. Pinophyta (Cupressaceae, Pinaceae and Sciadopityaceae). Grana 50: 262-310

Halbritter H, Hesse M (1995) The convergent evolution of exine shields in Angiosperm pollen. Grana 34: 108-1 19

Halbritter H, Hesse M (2004) Principal modes of infoldings in tricolp(or)ate Angiosperm pollen. Grana 43: 1-14 
Halbritter H, Hesse M (2005) Specific ornamentation of orbicular walls and pollen grains, as exemplified by Acanthaceae. Grana 44: 308-313

Havinga AJ (1971) An experimental investigation into the decay of pollen and spores in various soil types. In: Brooks J, Grant PR, Muir MD, Van Gijzel P (eds) Sporopollenin. Academic Press, London, New York, p. 446-479

Havinga AJ (1984) A 20-year experimental investigation into the differential corrosion susceptibility of pollen and spores in various soil types. Pollen spores 26: $541-558$

He X, Dai J, Wu Q (2016) Identification of Sporopollenin as the Outer Layer of Cell Wall in Microalga Chlorella protothecoides. Front Microbiol 7: 1047

Hesse $M$, Halbritter $H$, Zetter $R$, Weber $M$, Buchner $R$, Frosch-Radivo A, Ulrich S (2009) Pollen Terminology. An illustrated Handbook. Springer, Vienna

Hemsley AR, Barrie PJ, Chaloner WG, Scott AC (1993) The composition of sporopollenin and its use in living and fossil plant systematics. Grana 32, Suppl 1: 2-1 1

Huysmans S, El-Ghazaly G, Smets E (1998) Orbicules in angiosperms: morphology, function, distribution, and relation with tapetum types. Bot Rev 64: 240-272

Jardine PE, Fraser WT, Lomax BH, Gosling WD (2015) The impact of oxidation on spore and pollen chemistry. J Micropalaeontol 24: 139-149

John JF (1814) Ueber den Befruchtungsstaub, nebst einer Analyse des Tulpenpollens. J Chem Phys 12: 244-252

Johnson ST, Edwards TJ (2000) The structure and function of orchid pollinaria. Plant Syst Evol 222: 243-269

Klaus W (1960) Sporen der karnischen Stufe der ostalpinen Trias. In: Oberhauser R, Kristan-Tollmann E, Kollmann K, Klaus W (eds) Beiträge zur Mikropaläontologie der alpinen Trias. Jahrb Geol Bundesanstalt, Sonderband 5: $107-184$

Klaus W (1987) Einführung in die Paläobotanik. Fossile Pflanzenwelt und Rohstoffbildung, Band I. Grundlagen - Kohlebildung - Arbeitsmethoden/ Palynologie. Deuticke, Wien

Knox RB, McConchie CA (1986) Structure and function of compound pollen. In: Blackmore S, Ferguson IK (eds) Pollen and Spores, Form and Function. Linnean Society of London, London, p. 265-282

Lallemand B, Erhardt M, Heitz T, Legrand M (2013) Sporopollenin biosynthetic enzymes interact and constitute a metabolon localized to the endoplasmic reticulum of tapetum cells. Plant Physiol 162: 616-625

Leslie $A B$ (2010) Flotation preferentially selects saccate pollen during conifer pollination. New Phytol 188: 273 279

Liu L, Fan X (2013) Tapetum: regulation and role in sporopollenin biosynthesis in Arabidopsis. Plant Mol Biol 83: 165-175

Maeda $Y$ (1984) The presence and location of sporopollenin in fruiting bodies of the cellular slime moulds. J Cell Sci 66: 297-308

Pacini E, Franchi GG (1991) Role of the tapetum in pollen and spore dispersal. Plant Syst Evol, Suppl. 7: 1-11

Pacini E, Hesse M (2005) Pollenkitt - its composition, forms and functions. Flora 200: 399-415

PalDat - a palynological database (2000 onwards, www. paldat.org)

Phuphumirat W, Gleason FH, Phongpaichit S, Mildenhall DC (2011) The infection of pollen by zoosporic fungi in tropical soils and its impact on pollen preservation: a preliminary study. Nova Hedwigia 92: 233-244
Phuphumirat W, Zetter R, Hofmann C-C, Ferguson DK (2015) Pollen degradation in mangrove sediments: A short-term experiment. Rev Palaeobot Palynol 221: 106-116

Playford G, Dettmann ME (1996) Spores. In: Jansonius J, McGregor DC (eds) Palynology: principles and applications. American Association of Stratigraphic Palynologists Foundation, vol. 1, AASP Foundation, Dallas, p. 227-260

Pozhidaev AE (2000a) Pollen variety and aperture patterning. In: Harley MM, Morton CM, Blackmore S (eds) Pollen and Spores: Morphology and Biology. Royal Botanic Gardens, Kew, p. 205-225

Pozhidaev AE (2000b) Hypothetical way of pollen aperture patterning. 2: Formation of polycolpate patterns and pseudoaperture geometry. Rev Palaeobot Palynol 109: 235-254

Praglowski J (1975) Importance de la mise au point des terms "structure" de l'exine. Bull Soc Bot France, Coll Palynologie 122: 75-78

Punt W, Hoen PP, Blackmore S, Nilsson S, Le Thomas A (2007) Glossary of pollen and spore terminology. Rev Palaeobot Palynol 143: 1-81

Quilichini TD, Douglas CJ, Samuels AL (2014) New views of tapetum ultrastructure and pollen exine development in Arabidopsis thaliana. Ann Bot 114: 1189-120

Reitsma TJ (1969) Size modification of recent pollen grains under different treatments. Rev Palaeobot Palynol 9: 175-202

Riding JB, Kyffin-Hughes JE (2004) A review of the laboratory preparation of palynomorphs with description of an effective non-acid technique. Rev Bras Paleontolog 7: 13-44

Rowley JR, Skvarla JJ (2000) The elasticity of the exine. Grana 37: 1-7

Rubinstein CV, Gerrienne P, de la Puente GS, Astini RA, Steemans P (2010) Early Middle Ordovician evidence for land plants in Argentina (eastern Gondwana). New Phytol 188: 365-369

Schwendemann AB, Wang G, Mertz ML, McWilliams RT, Thatcher SL, Osborn JM (2007) Aerodynamics of saccate pollen and its implications for wind pollination. Am J Bot 94: 1371-1381

Simons J, Van Beem AP, De Vries PJR (1983) Structure and chemical composition of the spore wall in Spirogyra (Zygnemataceae, Chlorophyceae). Acta Bot Neerl 31: 359-370

Skvarla JJ, Rowley JR, Chissoe WF (1997) Exine resistance to fungal infestations in Strelitziaceae. Taiwania 42: $17-27$

Steemans P, Lepot K, Marshall CP, Le Herisseé A, Javaux EJ (2010) FTIP characterisation of the chemical composition of Silurian miospores (cryptospores and trilete spores) from Gotland, Sweden. Rev Palaeobot Palynol 162: $577-590$

Takahashi M (1995) Development of structure-less pollen wall in Ceratophyllum demersum L. (Ceratophyllaceae). J Plant Res 108: 205-208

Traverse A (1988) Paleopalynology. Unwin Hyman, Boston

Traverse A (2007) Paleopalynology. 2nd ed, Springer, Dordrecht

Tryon AF, Lugardon B (1991) Spores of the Pteridophyta: Surface, wall structure and diversity based on electron microscopy studies. Springer, New York

Tsou C-H, Fu Y-L (2002) Tetrad pollen formation in Annona (Annonaceae): Proexine formation and binding mechanism. Am J Bot 89: 734-747 
Twiddle CL, Bunting MJ (2010) Experimental investigations into the preservation of pollen grains: A pilot study of four pollen types. Rev Palaeobot Palynol 162: 621-630

Ueno R (2009) Visualization of sporopollenin-containing pathogenic green micro-alga Prototheca wickerhamii by fluorescent in situ hybridization (FISH). Can J Micro 55: 465-472

Ulrich S, Hesse M, Weber M, Halbritter $H$ (2017) Amorphophallus: New insights into pollen morphology and the chemical nature of the pollen wall. Grana 56: 1-36

Van Bergen PF, Collinson ME, de Leeuw JW (1993) Chemical composition and ultrastructure of fossil and extant salvinialean microspore massulae and megaspores. Grana 32, Suppl 1: 18-30

Van Campo M, Lugardon B (1973) Structure grenue infratectal de l'ectexine des pollens de quelques Gymnospermes et Angiospermes. Pollen Spores 15: 171-189

Versteegh GJM, Blokker P, Bogus KA, Harding IC, Lewis J, Oltmanns S, Rochon A, Zonneveld KAF (2012) Infra red spectroscopy, flash pyrolysis, thermally assisted hydrolysis and methylation (THM) in the presence of tetramethylammonium hydroxide (TMAH) of cultured and sediment-derived Lingulodinium polyedrum (Dinoflagellata) cyst walls. Org Geochem 43: 92-102

Verstraete B, Moon H-K, Smets E, Huysmans S (2014) Orbicules in flowering plants: A phylogenetic perspective on their form and function. Bot Rev 80: 107-134
Vinckier S, Cadot P, Smets E (2005) The manifold characters of orbicules: structural diversity, systematic significance, and vectors for allergens. Grana 44: 300-307

Walker JW (1976) Evolutionary significance of the exine in the pollen of primitive angiosperms. In: Ferguson IK, Muller J (eds) The evolutionary significance of the exine. Academic Press, London, p. 251-308

Wallace S, Chater CC, Kamisugi Y, Cuming AC, Wellman $\mathrm{CH}$, Beerling DJ, Fleming AJ (2015) Conservation of Male Sterility 2 function during spore and pollen wall development supports an evolutionarily early recruitment of a core component in the sporopollenin biosynthetic pathway. New Phytol 205: 390-401

Weber M, Halbritter $H$ (2007) Exploding pollen in Montrichardia arborescens (Araceae). Plant Syst Evol 263: $51-57$

Wellman $\mathrm{CH}$ (2010) The invasion of the land by plants: when and where? New Phytol 188: 306-309

Wiermann R, Ahlers F, Schmitz-Thom I (2001) Sporopollenin. In: Hofrichter M, Steinbüchel A (eds) Biopolymers 1: Lignin, Humic Substances and Coal, Wiley-VCH Weinheim, p. 209-227

Yule BL, Roberts S, Marshall JEA (2000) The thermal evolution of sporopollenin. Org Geochem 31: 859-870

Zetzsche F, Kalt P, Leichti J, Ziegler E (1931) Zur Konstitution des Lycopodiumsporonins, des Tasmanins und des Lange-Sporonins. J Prakt Chem 148: 67-84

Open Access This Chapter is licensed under the terms of the Creative Commons Attribution 4.0 International License (http://creativecommons.org/licenses/by/4.0/), which permits use, sharing, adaptation, distribution and reproduction in any medium or format, as long as you give appropriate credit to the original author(s) and the source, provide a link to the Creative Commons license and indicate if changes were made.

The images or other third party material in this chapter are included in the chapter's Creative Commons license, unless indicated otherwise in a credit line to the material. If material is not included in the chapter's Creative Commons license and your intended use is not permitted by statutory regulation or exceeds the permitted use, you will need to obtain permission directly from the copyright holder. 